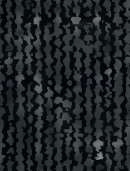

(1)

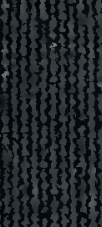

3 



T'HE

\title{
TRANSACTIONS
}

$\mathrm{OH}$

\section{THE LINNEAN SOCIETY OF LONDON.}

\author{
THE PERCY SSLADEN TRUST EXPEDITION \\ To \\ THE INDIAN OCEAN IN 1905, \\ UNDER THE LEADERSHIP OF \\ Mr J. STANLEY GARDINER, M.A. \\ VOLUIME IV.
}

No. XIX.—DIPTERA： LONCHAIDE, SAPROMYZIDE, EPHYDRIDE, CHLOROPIDE, AGRONYZIDA.

By C. G. Lamb, M.A., B.Sc., Clare College, Cambridge.

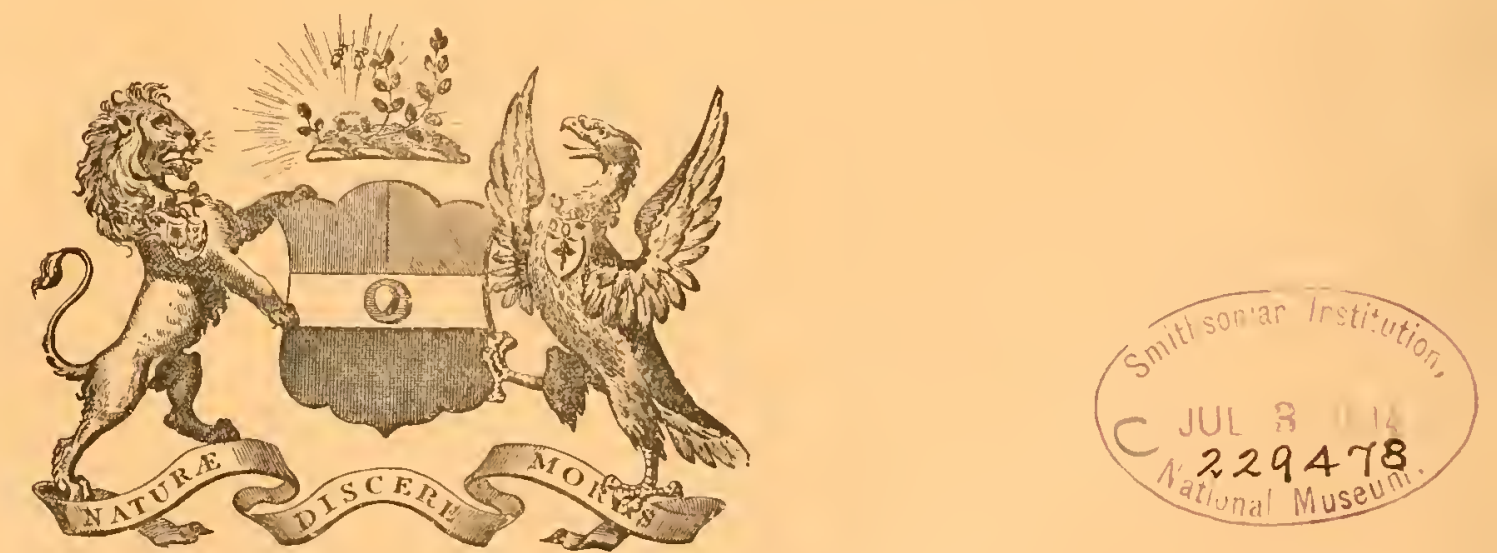

L O N D ON :

PRINTED FOR THE LINNEAN SOCIETY

BY JOHN CLAY, M.A. AT THE UNIVERSity PRESS, CAMBRIDGE.

SOLD AT THE SOCIETY'S APARTMENTS, BURLINGTON HOUSE, PICCADLLLY, $W$., AND BY LONGIANS, GReEN, AND CO., PATERnoster-Row. 

No. XIX._DIPTERA: LONCH EIDE, SAPROMYZIDA, EPHYDRID \&, halles rae

CHLOROPIDE, AGROMYZIDE.

By C. G. Lamb, M.A., B.Sc., Clare College, Cambridge.

(Plates 15, 16 and Text-Figures 1-33.)

(Communicated by Professor J. Stanley Gardiner, F.R.S., F.L.S.)

Read 20 June, 1912.

\section{Lonchæidæ.}

LONCHea, Fallén.

Lonchrea Fallén, Dipt. Suec., Ortal., (1820), p. 25.

1. Lonchcea splendida Loër, Beschr. Europ. Dipt., iii. p. 29\%.

Several specimens of this fine species were collected. It is known from the Mediterranean Region.

Localities. Seychelles. Bird Island, VII. 1908 (Fryer). Dennis Island, VIII. 1908 (Fryer). Mahé: Cascade Estate, about $800 \mathrm{ft}$. and over, 1908-9. Praslin : Côtes d'Or' Estate, XI. 1908.

\section{Lonchaed plumata, n. sp.}

This is a black species with black legs; the calypters are pale and pale-laaired; there is a long terminal abdominal segment in the s like that of $L$. incequalis, Loëw.

f. The whole insect is uniformly black, including the legs.

Head (Pl. 15, fig. 1). Frons nearly parallel-sided, slightly narrowing from the vertex to the front fronto-orbital bristle. The vertex and the narrow eye-margins as far as the insertion of the fronto-orbital bristles are very shining. The rest of the frons (including the lower part of the eye-margins) is dull, but the space below the lunule and between the antennal bases is covered with shining dust. The lower eye-margins are black. Labrum just visible in front, antennal foveæ shallow but evident. The face widens rapidly from the frons to the month.

Eyes large, very long-oval in profile, bare.

Antennæ with second joint somewhat greyish, third joint long and laterally compressed, slightly concave in front in side view with a rounder tip, about four times as long as broad, with tip extending almost to the mouth margin. Arista pale and thickened

SECOND SERIES-ZOOLOGY, VOL. XV. 
at the base, then black; it is very beautifully feathered, each ray being shaped like an elongated S: there are abont 18 rays each side. Palpi stout, fleshy, black and hairy, somewhat compressed sideways.

One pair of fronto-orbital bristles, two pairs of verticals, the outer much weaker than the inner, a fine pair of forwardly-directed divergent post-verticals, stout ocellars : in profile the frons is seen to be finely haired all over.

Thorax. Dorsum clothed with adpressed hairs, but the hind part is bare. Scutellum duller and greyish in colour. Bristles normal.

Wings (Fig. 1) pellucid with yellow veins, the fine costal ciliation black. Calypters small, whitish yellow, pale-margined and white-haired.

Halters black with paler stalks.

Legs. Front: femora with two rows of long bristly hairs; tibiæ and tarsi clothed with short bristly hairs. Middle: femora all covered with short bristly hairs, an inferior posterior row of longer ones is conspicuous; tibia with similar fine bristles and a terminal crown of spines; tarsi with black bristly hairs. Hind: covered with fine bristly hairs, among which is a somewhat conspicuous row below the femora.

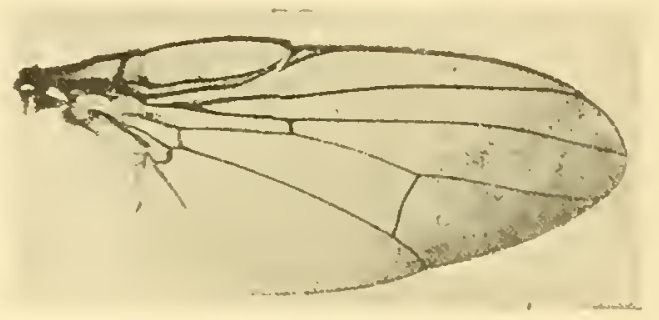

Fig. 1. Lonclecea plumata, n. sp., wing.

Abdomen. 5. The last segment is slightly longer than the two previous ones together (Pl. 15, fig. 2) and has the form of a truncate triangle with the end notched. 'The two angular tips thus formed bear' a bunch of black bristly hairs. The whole surface dorsal and ventral is covered with similar hairs which are stouter on the margins of the segments and towards the end of the last segment.

q like the male, except as follows:-Face about one-third as wide again as that of the male; abdomen with equal segments except the one before the ovipositor, which is a little narrower; the ovipositor is shining black, acicular, scarcely flattened, the sheath is paler.

Size about $4 \mathrm{~mm}$.

Localities. Seychelles. Silhonette: Mare aux Cochons, over $1000 \mathrm{ft} .$, IX. 1908. Mahé : Port Victoria, XII. 1908; Long Island, VII. 1908; Anonyme Island, I. 1909; marshy ground near sea-level at Cascade, 20. II. 1909 ; cultivated country about $1000 \mathrm{ft} .$, XI.-XII. 1908; near Morne Blanc, about 800 ft., X.-XI. 1908 ; Cascade Estate, 800-1700 ft. and orer; 1908-9 ; forest behind Trois Frères, about 2000 ft., 14. I. 1909 ; Nare aux Cochons district, about $1500 \mathrm{ft.,}$ I.-II. 1909.

3. Lonchere longicomis, n. sp.

A shining bluish-black species with red metatarsi, pale calypters with pale hairs. 
3. Head (Pl. 15, fig. 3). Vertex and frons somewhat shining and slightly hairy; eye-margins smoother and more shining, especially from the vertex to the fronto-orbital bristles: the front part of the frons and the lower part of frontal eye-margins dull. The upper part of the eye-margins narrows considerably from the vertex to the fronto-orbital bristles. A silvery spot lies between the bases of the antemne. Face with silvery dust and a well-marked narrow central linear keel; the face widens rapidly from the antennæ to the mouth. Antemm close to eyes, so that in fiont view the antennæ are markedly divergent. Eyes bare.

Antenne black with the third joint somewhat dusted inside, it is very long and nearly parallel-sided, with an evenly-rounded tip extending in side view well below the mouth margin; arista long, and microscopically pubescent, brownish at the base, the rest black.

One fronto-orbital bristle, fine post-verticals, long ocellars; frons fine-haired in profile.

Palpi fleshy, black and hairy.

Thorax. Dorsum bristly-haired, both it and the plenræ are shining black with a distinct blue tinge. Scutellum also shining black but with a faint greenish tinge. Bristles normal.

Wings normal: venation much as the last species, but with the lower cross-vein slightly more oblique; brownish in colour, with yellow-brown veins.

Calypters pale with pale borders and hairs.

Halters all black.

Legs black except that all the tarsi are reddish-yellow. Front: femora with the usual two rows of bristles with some irregular and shorter bristles between; the npper backwardly-directed row is regular, the lower downwardly-directed row has five or six bristles which are not so long as usual. Middle: femora with a regular row of strong hairs below ; tibiæ with only one stout inner bristle of the terminal crown evident. All the legs covered with fine bristly hairs.

Abdomen. Ovate in outline with nearly equal segments and a bluntly-pointer tip. From a top view it is seen to be bordered with long fine black bristles; the onter comers of the second segment with abundant black hairs; dorsum with longish bristly hairs but no very evident marginal bristles.

i. Frons wider than in male, nearly parallel-sided. Oripositor long black nonflattened with a black sheath; when fully extended it is nearly as long as the rest of the abdomen.

Size about $3 \mathrm{~mm}$.

Loculity. Seychelles. Mahé: Cascade Estate, abont 1000 ft., 1908-9.

4. Lonchere vibrissifer, n. sp.

A black species with yellow metatarsi, calypters pale and pale-haired, and with very long vibrissa. 
§. Head (Pl. 15, fig. 4). Frons dull, slightly narrowing from the vertex to the antennæ; in side view it is seen to be bristly-haired; the bristles on the eye-margins bend backwards, those on the disc of the frons bend forwards, so that in profile the frons appears to be covered with bristles crossing about at right angles. Upper eye-margins which include the vertical and fronto-orbital bristles are bristly, slightly shining and rather short. Face slightly silvery, widening rapidly from antennæ to mouth. Jowls very evident, blackhaired. Eyes bare.

Antennæ: third joint black, slightly dusted, short, about twice as long as broad: when looked at from in front the tip of the antenna does not reach the curved mouth margin by about half the length of the third joint. Arista pale at base then black, microscopically pubescent.

The bristles are normal, the ocellars being stout. There is a prominent stout vibrissa on each side of the mouth.

Palpi retracted, brownish black.

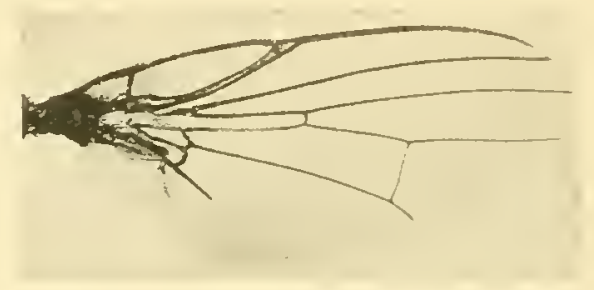

Fig. 2. Lonchrea vibrissifer, n. sp., wing.

Thorax. Shining black with normal bristles and stout bristly hairs extending nearly up to the prescutellar bristles. Scutellum same colour as thorax.

Wings (Fig. 2) brownish in tone with brown-yellow veins. Calypters pale with pale borders and hairs.

Halters black with stalks slightly paler in the middle.

Legs all black except that the metatarsi and the next joint in the front and middle legs and the next two joints in the hind legs are yellow. The front femora have the inferior row of bristles longer than usual, forming a regular comb. Middle femora with a stout ciliation below and the tibiæ with no crown of spines.

Abdomen similar to the last species but somewhat more truncate at the tip.

it with a wider frons, the ovipositor short and much flattened, with a pale sheath.

Size a little over $3 \mathrm{~mm}$.

Localities. Seychelles. Silhouette: platean of Mare aux Cochons, over $1000 \mathrm{ft}$., IX. 1908. Mahé : Cascade Estate, about $1000 \mathrm{ft}$; Morne Seychellois, orer $1500 \mathrm{ft.}$ 4. II. 1909. 


\section{Sapromyzidæ.}

Pachycerina, Macquart.

Pachycerina Macquart, Suite ì Buffon, ii. (1835), p. 511.

5. Pachycerina seychellensis, n. sp.

This species must be closely related to $P$. javance Macq.

๙. Head (Pl. 15, fig. 6). Frons dull yellow orange, paler towards the vertex; the ocellar spot dull black, nearly circular, but slightly diawn out to the vertex. The two fronto-orbital bristles stand on greyish spots, the spot of the hind one is the larger and is connected to the vertex by a continuing pale greyish line. Face very shining yellow fiom just above the antennal base to the mouth margin; it has the usual two roundish black shining spots. Palpi with black heads, the rest yellow. Tongue yellow.

Two fronto-orbitals, inner and outer verticals, crossed post-verticals, very fine ocellars between the ocelli, and a very fine pair on the vertical black spot just at the vertex. Hind head bristled on the eye-margins below the outer verticals. A fine row of hairs bordering the cheeks and on the jowls.

Antenne yellow; the first joint pyriform, second cylindrical, bristled at the apex beneath and at the base on top, third very long and gradually tapering to a blunt end; arista black with very dense stout feathering.

Thorax. Dorsum shining, marked longitudinally with brownish and yellowish stripes. Three dorso-central bristles, the last two in the same transverse row as the prescutellar pair of bristles, and two regular rows of achrosticals. The surface has also various scattered hairs; some of these form well-defined side rows of small bristles, seen best on viewing the thorax sideways; one such row is a continuation of the dorso-central bristles, another runs roughly parallel to the line of those bristles, but is more remote from the centre line of the dorsum; this row begins a little before the front dorso-central bristle and ends a little before the third. The yellowish stripes are between the achrostical rows and on the line of the dorso-centrals, and extend to the front of the thorax; between these three rows are the two brownish stripes. A similar short brownish stripe runs from the intra-humeral bristle to the front of the thorax; between this and the three posthumeral bristles the humeri and dorsum are again yellow, which colour continues from the side row of bristles over to the hind part of the pleuræe.

Pleuræe yellow with a broad brown stripe extending from the wing base to the front, a similar narrow stripe on the sterno-plemral suture.

Scutellum yellow, slightly darkened centrally and at the base, disc somewhat fiattened, the usual four strong bristles.

Wings normal in venation, yellow but slightly darkened along the costal edge; veins yellow.

\section{Halters yellow.}

Legs with the usual preapical tibial bristle. Front: femora yellow, brownish on the upper surface with three rows of stout bristles, the underneath row the strongest, tibia 
black with extreme tip yellowish; tarsi all black, the last joint with long hairs on the dorsal surface. Middle: all yellow with a crown of two spines on the end of the tibia. Hind: yellow.

Abdomen. Shining yellow brown to blackish with a few scattered hairs; the hind margin of the segments with a row of very long bristles, especially well developed on the third and fourth segments, these marginal bristles extend over the sides. The terminal segments of the $f$ form a distinct hypopygium of rounded ontline, a ventral view of which is given in Pl. 15, fig. 5 ; the last segment has a pair of projecting processes with a fine horny process between. Sixth segment with two black dots.

+. The female is similar to the male but has a somewhat pointed abdomen. Size, excluding antennæ, $4 \mathrm{~mm}$.

Localities. Seychelles. Silhouette: near Mt. Pot-à-eau, about 1500 ft., VIII. 1908; Mare aux Cochons, IX. 1908. Mahé : Long Island, VII. 1908; marshes on coastal plain, Anse aux Pins and Anse Royale, I. 1909 ; from grass in cultivated country, about $1000 \mathrm{ft}$., XII. 1908 ; near Morne Blanc, 800 ft., XI. 1908 ; Cascade Estate, ca. 1000 ft., 1908 -9.

6. Pachycerina obscuripennis, n. sp.

In general form and characters this species is much like the last, it is, however, a very dark suffused form. 'The differences are given below.

๙. Head. The ocellar spot is elliptical in outline, extending over the vertex with the hind pair of ocelli standing on its minor axis. The grey line joining the vertex to the upper fronto-orbital bristle is more evident and broader. Antennæ: first and second joints dark brown, the second with more hairs, arista more densely haired.

Thorax. Dorsum all black brown, the colour extending right up to the scutellum, with a fine yellow line between the achrostical bristles and a yellow border extending from the humeri to round the edge of the scutellum.

Wings suffused with black, darkening towards the costa.

Halters black.

Legs, front femora yellow with a black tip.

Abdomen. All shining black with appendages like those of the former species. Size as last species.

Locality. Seychelles. Silhonette: forest above Mare aux Cochons, IX. 1908.

Sapromyza, Fallén.

Sapromyza Fallén, Dipt. Suec., Ortal., (1820), p. 29.

Sub-gren. SApromyza, sens. str.

7. Sapromyza striata, n. sp.

This species has the general appearance and the long plumose antenna of the sub-genus Minettia, but it has only one intra-alar bristle visible. 
Head (Pl. 15, fig. 7). Frons dull, whitish yellow, a slightly darker indistinct stripe extends from the vertex to the base of the antennæ. Face white. Back of head yellow behind the vertex, blackish behind the eyes; below the yellow part are two silvery dots with black bristly hairs on them. Chætotaxy nomal, but the post-verticals long and crossed not merely convergent.

Antemne yellow, slightly darkened inside at the tip; arista brown at base with black flagellum, long haired on the top with about 15 rays, shorter rayed below.

Palpi black; tongue pale.

Thorax. Dorsum pale brownish white with two broad brown stripes extending from just above the shoulders over dorsum and over scutellum where they are confluent, so that the scutellum may be said to be brown with whitish sides. Between the two brown dorsal stripes is a whitish stripe, all three being of approximately equal breadth in front. Chetotaxy normal with three dorso-centrals; the achrosticals are arranged in eight roughly parallel and equidistant rows of equal sized bristles. Pleuræe yellowish white.

Wings as Fig. 3 ; spotted, with yellow veins.

Halters yellow.

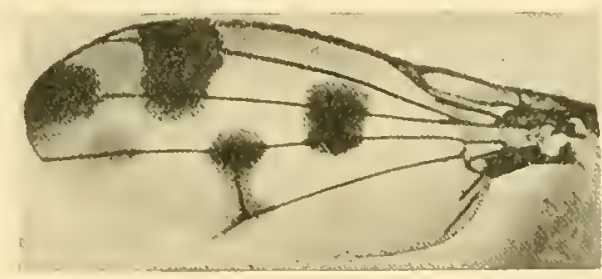

Fig. 3. Sapromyza striate, n. sp., wing.

Legs all yellow. Front: femora with conspicnous rows of spines on the lower and hind sides. Middle: femora with a row of five spines on the front side at the tip; tibiae with a crown of spines at the tip. All the legs have the usual covering of small bristly hairs.

Abdomen. Yellow, the boundaries of the segments edged with black, the edging of all but the third segment being marginal, that of the third somewhat remote from the margin. A black and slightly interrupted median line runs along the dorsum of the third to the fifth segments joining each transverse black line to the base of the segment.

Size, excluding the antennæ, $4 \frac{1}{2} \mathrm{~mm}$.

Localities. Seychelles. Silhouette: near Mt. Pot-à-eau, about $1500 \mathrm{ft} .$, VIII. 1908 ; Mare aux Cochons and forest above, IX. 1908. Mihé : high damp forest between Trois Frères and Morne Seychellois, about 1500-2000 ft., XII. 1908. Praslin: Côtes d'Or Estate, XI. 1908. Félicité: forest, XII. 1908.

Note. This species must be closely related to Lauxania (Sapromyza) bilineatre Speiser, Wiss. Ergebnisse d. Schwed. Zool. Exp. nach dem Kilimandjaro, Dipt. p. 173.

The next two species are structurally very similar as regards shape of head, nature of chrtotaxy, size, etc. The principal difference is in the antennæ. 
8. Sapromyza funebricomis, n. sp.

Head (Pl. 15, fig. 8). Frons dull brownish yellow, eye-margins and ocellar spot somewhat shining. Face whitish yellow, jowls with scattered bristles, vertex bristly along edge from centre round the eye-margins. Antennæ with first two joints brownish, third joint black; arista sub-plumose, black, the basal joint pale.

Palpi pale, filiform, with a few long bristles on the lower side.

Chrtotaxy normal, post-verticals crossed about half-way; all the bristles stont.

Thorax. Greyish yellow, uniformly covered with tiny bristles; between the dorsocentral rows these form the achrostical bristles which are somewhat irregularly arranged in six rows, the four middle rows being fairly regular and equidistant, the bordering rows more irregular.

Chretotaxy normal with $(1+2)$ dorso-centrals, humeral, two post-humeral, one presutural, two supra-alar, one intra-alar, two prescutellar.

Scutellum the same colour as the thorax, broadly rounded at the tip.

Wings (Fig. 4) slightly tinged with yellow; veins yellow.

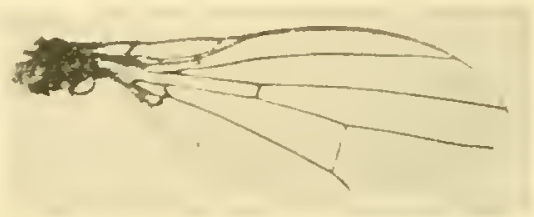

Fig. 4. Saynomyze fumebricomis, n. sp., wing.

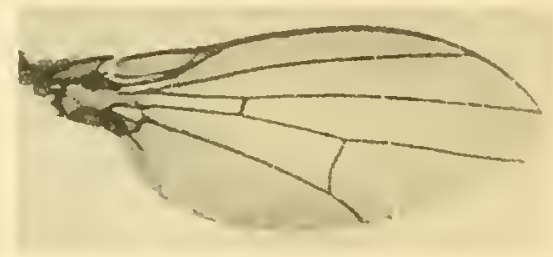

Fig. 5. Sapromyzn mahensis, n. sp., wing.

Halters yellow.

Legs all yellow. Front femora with the usual two rows of bristles towards the end on the posterior side, both upper and lower rows have about three bristles; the interior lower side (where it would be clasped by the tibia if the leg were closed) has a distinct row of tiny bristles on the tip third. Middle femora with a stout row of some five bristles on the distal end of the anterior side, tibiæ with a crown of spines. Hind femora evidently ciliated beneath, the ciliation beginning at the middle and getting longer towards the tip. The bristly hairs so commonly present on the ventral parts of the middle and front sternopleuræ and on the coxæ are very well developed.

Abdomen. The same colour as the thorax; margins with stout bristles which extend over to the margin of the succeeding segment. The surface has scattered hairs. The segments diminish slightly in size from the second to the last.

In the male there is a slightly swollen hypopygium, but none of the specimens possessed the appendages referred to in the next species.

Size, excluding antenne, $3 \frac{1}{2} \mathrm{~mm}$.

Localitics. Seychelles. Silhonette: low coconut-planted country near the coast, Pointe Étienne, 17. IX. 1908; Mare aux Cochons plateau, one specimen, IX. 1908. 
Mahé: marshes on coastal plain, Anse aux Pins and Anse Royale, T. 1909; Long Island, VII. 1908; Anonyme Island, I. 1909 ; Mare aux Cochons district, 1000_-2000 ft., one specimen, I.-II. 1909. All the specimens except two (indicater above) are from near the coast.

9. Sapromyza mahensis, n. sp.

This species is very closely allied to the preceding with which it is compared.

Head. Form very like last: antenne all pale yellow; third joint slightly larger; arista differs as follows: in S. fumebricornis the top rays are long at base and diminish to the tip, the lower rays are finer and shorter at the base than at the apex so that the upper and lower rays are of about equal length for the distal two-thirds of the arista: in S. mahensis the rays are finer, more distant and on the top are of equal length for about the first two-thirds of the arista; below they are nearly as long as above, fine and also equally long for the first two-thirds of the arista. The venation (Fig. 5) differs slightly as will be seen from Figs. 4 and 5 .

The bunches, of hairs on the sterno-pleuræ and coxæ are less stout. The whole insect is more shining and of a clearer yellow colour.

In a few specimens the male genitalia are extruded (Pl. 15, figs. 9, 10). These bave a median lobe hooked at each side and notched in the middle, two side hooked appendages and a little fleshy hump covered with hairs. In most specimens this is retracted, when the insect has a somewhat swollen knobby, hypopygium.

Size as last species.

Localities. Seychelles. Mahé : Long Island, VII. 1908; Anonyme Island, from grass, etc., I. 1909 ; marshes on coastal plain, Anse aux Pins and Anse Royale, I. 1909; cultivated comntry near sea-level at Cascade, II. 1909.

10. Sapromyza nudiuscula, 11. sp.

Head (Pl. 15, fig. 11). Frons and face entirely the same dull bright yellow: clypens visible in front: mouth margin slightly but sharply produced as seen in profile. Antennæ bright yellow, third joint shortish oval, arista brownish but pale at the base and very finely pubescent.

Palpi yellow, narrow, with a few fine hairs.

Bristles less strong than the last two species.

Thorax. Dorsum yellow to brownish yellow covered with fine black bristles $(1+2)$ dorso-centrals: achrosticals in four regular rows with no irregular bordering ones. Chrtotaxy quite normal with smaller and less stout bristles than the preceding two species. Scutellum distinctly flattened on the disc.

Wings narrower but with venation like S. mahensis, barely tinged with yellow; veins pale.

Halters yellow.

Legs all yellow. Front femora with the usual two rows of bristles behind both very long; the upper row has six to seven bristles and extends from base to tip of femur, the SECOND SERIES-ZOOLOGY, VOL. XV. 
lower row has four bristles, the basal ones being the longer, and also extends all along the femur. Middle tibire with the terminal crown reduced to one long bristle inside. Hind femora with one or two fine terninal bristles outside, tibiæ with one very short stout spine at the end.

The coxal and sterno-plenral hair bunches are sparser and shorter than in the last species.

Abdomen. Yellow; surface bristly; marginal bristles present; segments of nearly equal length.

Size about $3 \mathrm{~mm}$.

Localities. Seychelles. Mahé: near Morne Blane, X. 1908. Silhouette: near Mt. Pot-ì-eau, about $1500 \mathrm{ft} .$, VIII. 1908.

\section{Sapromyza crassicaput, n. sp.}

A single specimen was collected of this species, which is at once distinguished by its unusually large head. It has two brown-black spots on the fourth abdominal segment; except for this and the somewhat infuscate front legs, it is entirely yellow.

o. Head (Pl. 15, fig. 12). The frons is a slightly duller but brighter yellow than the rest of the insect: ocelli reddish. Back of head with regular bristles recalling the post-ocular bristles of the Dolichopidar; cheeks bristly.

Palpi yellow and hairy. The usual two fronto-orbital bristles present, inner and outer verticals, post-verticals somewhat below the vertical margin towards the back of the head and crossed, ocellars more delicate.

Antenne all yellow including the basal joints of the arista, third joint fairly long, aristal flagellum black and slightly pubescent.

Thorax. Three dorso-centrals; the arrangement of the achrosticals is rather difficult to observe as the dorsum is depressed by the pin, they appear to be irregularly six-rowed. Other bristles normal.

Wings normal, glassy with yellow veins.

Halter's yellow.

Legs yellow except that the front pair are slightly infuscate, especially on the tibire and tarsi, and that the middle tarsi are the same. Front femora with the usual row of backwardly-directed bristles above and a row beneath.

Abdomen. Finely haired; marginal bristles on all but the middle part of the segments. A large black spot on each side of the fourth segment occupying nearly the whole breadth.

Size, excluding the antennæ, $3 \frac{3}{4} \mathrm{~mm}$.

Locality. Seychelles. Mahé: Cascade Estate, $800 \mathrm{ft}$. or more.

12. Sapromyza perpunctata, n. sp.

A single specimen was collected belonging to the group with pictured wings.

Head (Pl. 15, fig. 13). Vertex and frons brown, yellow above the antennæ. The ocelli on a distinct tubercle, fronto-orbital bristles on small black spots. Face brown. 
Two fronto-orbital bristles, verticals, post-verticals a little below vertex on back of head, ocellars. Antennæ: first two joints dark brown, third paler'; arista pale with fine pubescence.

Thorax. Black-brown variegated with ochreous patches. Dorso-central bristles $(1+3)$ each standing on a black spot in the ochreous patch. Pleure black-brown with ochreous-grey patches, the bristles standing on small black spots on the grey patches. Scutellum as thorax with a pale terminal and two side spots.

Wings variegated as in Fig. 6; darkened between costa and fourth vein, a white spot behind anxiliary vein, three (the middle smallest) between the costa and first vein, two between first and second, two rows of small spots between third and fourth, a spot in front of cross-vein; tip between second and third white. Between the fourth vein and the margin the wing is marked like that of a Tephritid.

Halters black.

Legs: femora all ringed with two black and two ochreous rings, beginning with a proximal black ring; tibire yellow with an indistinct ring proximally. Tarsi all yellow.

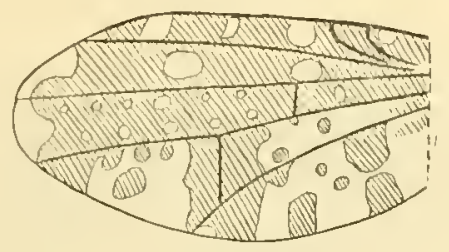

Fig. 6. Sapromyza perpunctata, n. sp., wing.

Front femora with the usual backwardly-directed top row of bristles and an underneath row, the latter long. The middle tibia have a fine terminal spine in addition to the preapical bristle.

Abdomen. Brownish-black like the thorax. On each distal and proximal margin is a central triangular pale spot, the proximal ones being the larger; the apices of these meet in the case of the second segment and nearly meet in the others, hence this row of spots forms an interrupted median line: on the distal margin of each segment there is also a row of pale circular spots three each side on the second segment, two ench side on the third, fourth and fifth; each pale spot has a black central dot from which proceeds a marginal bristle. There are also a few other minute dots near the proximal margin of the segments and on the disc of the same.

Size, excluding antenna, $2 \frac{3}{4} \mathrm{~mm}$.

Locality. Seychelles. Mahé: Cascade Estate, about 1000 ft., 1909.

Sub-gen. Homoneura, De Meijere.

Homoneura De Meijere, Tijdschr. voor Entom., li. (1908), p. 142.

Three species belong to this sub-genus, but none of them fit in with the characters in the table given by De Meijere (l.c.), nor with any hitherto published descriptions. 
13. Homoneura varifrons, n. sp.

Head (Pl. 15, fig. 14). Dull-black behind and forward to before the antennæ where the frons is bright orange-yellow: the side stripes on which the fronto-orbital bristles stand are shining brown-black and extend far forward on the frons to the yellow crossline: the margins between these stripes and the eyes are distinct fiom the stripes and are dark reddish-brown; the ocellar spot is shining, and a long-pointed frontal triangle extends forward from the spot which is perceptibly more shining than the rest of the central part of the frons though its boundary is not well defined. The face is entirely orange-yellow as are the eye-margins below and the jowls.

Antenne: first and second joints dark orange, third with its apical two-thirds blackish, the rest of it dark orange; the degree of darkening is somewhat variable. Arista with the basal joint and first part of second stout, basal joints pale, flagellum black with a black plumosity, which is longest at the base and tapers thence to the tip, the rays below are shorter and of fairly equal length.

Palpi darkened orange, especially on the under surface. Tongue orange with fleshy tip. Head bristles normal; a row of fine bristles on the lower eye-margin above the month edge; jowls bristly.

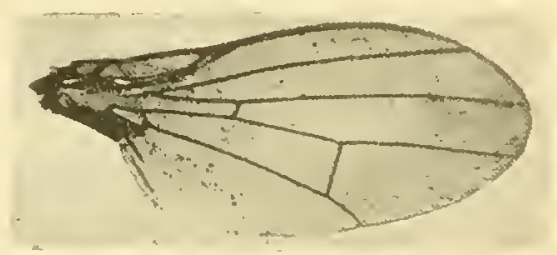

Fig. 7. Homoneura varifrons, n. sp., wing.

Thorax. All completely black, moderately shining; dorsum with a very faint brown pollination, pleuræe very slightly shining. Bristles normal, prescutellars rather small, achrosticals in six rows. Pleuræ very slightly silvery.

Wings (Fig. 7) almost glassy, very slightly tinged with yellow; veins yellow.

Halters with dark knobs and yellow stalks.

Legs. In the two males the legs are all pale yellow; front femora with the usual two rows of bristles behind, top row with about six equal bristles, lower row three towards the tip succeeded by a ciliation. Middle femora with two bristles at the end which are longer than the other normal bristles, tibix with a crown of two long bristles as well as the usual preapical one. Hind femora with an evident preapical bristle on the front side.

Abdomen. Black with marginal bristles and small ones on the surface. The male genitalia much as Pl. 15, figs. 9, 10 but not extruded.

The females, in most cases, have slightly darkened middle and hind femora, the darkening extending nearly all over the joints; the extent of this suffusion varies, and in one case the legs are pale like the male.

Size, excluding antenna, about $2 \frac{3}{4} \mathrm{~mm}$. 
Localities. Seychelles. Silhonette : Mare aux Cochons, over 1000 ft., VIII.-IX. 1908 ; near Mt. Pot-à-eau, abont 1500 ft., VIII. 1908. Mahé : Cascade Estate, ca. 1000 ft., 1908-9 ; Anonyme Island, from grass, etc., I. 1909.

\section{Homoneura atra, 11. sp.}

This species is in facies exceedingly like the last. The thorax and abdomen are also completely black, but the slight pollination is practically absent, and the pleuræ are not slightly silvery. The differences between the two species are given below.

Head. Frons, face and jowls entirely black except for a small brown space just above the antennæe and the brownish lower eye-margins. Antenna with the third joint brown, the others black. Palpi black.

All the legs are slightly darker orange; front femora darkened, middle and hind femora quite black.

Size as last.

Locality. Seychelles, Silhouette: Mare aux Cochons, over 1000 ft., IX. 1908.

15. Homoneura pulchrifions, n. sp.

Head. The central area of the frons is of a very striking deep velvety black; the side stripes on which the fronto-orbital bristles stand are broad and shining black, they extend right up to the eyes and are joined across the vertex by a narrow shining strip from which the front point of the small shining ocellar triangle projects. The back of the head is also shining black except for a central silvery spot. Face with the top half shining black, the lower half yellow, the broad eye-margins are paler yellow. Below the antemm on each side of the eye-margin is a silvery spot. Jowls yellow.

Palpi black, tongue yellow.

Antennæe entirely velvety black, arista plumose with the longest rays on top at base tapering to the tip, shorter and more uniform in length below.

Thorax. Dorsum somewhat shining brownish black, slightly dusted, with the humeral calli and a line from them over the wing bases brownish yellow: sterno-pleurie brown. Scutellum as the thorax but slightly paler round the margin and pale below, the metanotum is yellow.

Wings slightly yellow, tinged with brown-yellow veins.

Halter's yellowish with browner knobs.

Legs all yellow : front femora with the usual two rows of biistles, the upper extending nearly to the base with five or six bristles, lower with two distinct bristles on the distal third : middle femora with a distal row of four or five bristles on the front side, tibiæ with a crown of two spines as well as the preapical bristle; hind femora with small preapical bristle.

Abdomen. Moderately shining black, with marginal bristles and small general bristles.

Male hypopygium with a central lobe and two side hooks, the central lobe itself ending in two hooks. 
Size as last species.

Localities. Seychelles. Silhonette: from near Mt. Pot-ì-eau, about $1500 \mathrm{ft}$., VIII. 1908; Mare aux Cochons and forest above, IX. 1908. Mahé : from near Morne Blanc, X. 1908; high forest of Morne Blane and Pilot, XI. 1908; Mare aux Cochons district, about 1500 ft., I.-II. 1909. Praslin : Côtes d'Or Estate, XI. 1908.

\section{Ephydridæ. Notiphilinæ.}

Aсалтнолоттрнila, n. g. (Pl. 15, fig. 23).

This genus comes near Notiphila, Fallén.

Head. Eyes longish oval with the major axis vertical and the radius of curvature greater at top than bottom. Jowls present. Face and frons broad, nearly parallel-sided, in profile somewhat hollowed beneath antenne. Hind bead somewhat protuberant. Vibrissæ present. Prelabrum visible.

Bristles; immer and outer verticals, two upper fronto-orbitals (bent outward), two lower (bent forward); divergent ocellars; fine post-verticals, two pairs of stont bristles on the frons.

Antenna as in Notiphila; the second joint bristly with a very stout terminal spine; the arista with few rays (three in the typical species).

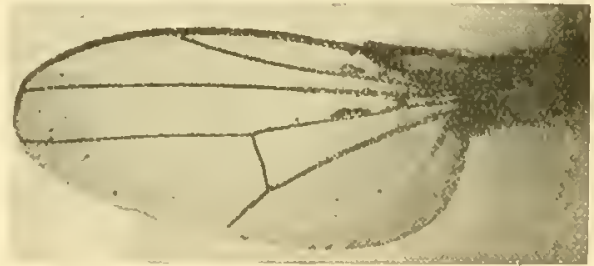

Fig. 8. Acanthonotiphila coriacea, n. g. et n. sp., wing.

Thorax and scutellum covered with stout bristly hairs, which are arranged in moderately regular rows; they are similar in character all over the dorsum so that there is no distinction between the achrostical and the other rows. A pair of prescutellars but no definitely assignable dorso-centrals: one humeral, one intra-humeral, two noto-pleural, two supra-alar, four scutellar (the terminal pair crossed at the tips), two meso-plenral, one sterno-pleural.

Wings (Fig. 8), costa to third vein but also rather thickened between third and fourth veins, bristly to the first, the last bristle being longer and like a small spine; third vein with three or four bristles on the dorsal side, where it is met by the second vein.

Abdomen with segments of nearly equal length.

The texture of the insect is cor'iaceons.

Type, the following species.

16. Acanthonotiphila coriacea, n. sp. (Pl. 15, fig. 23).

Head. Frons darlish grey, the bristles standing on minute black spots; the frontal triangle is marked out by two rows of slightly converging fine hairs which begin from the 
inner vertical bristles. Inside the triangle stand the ocellar bristles, two smaller slightly convergent bristles just beyond the front ocellus, and two stont parallel bristles nearly in a line with, but proximate to, the line joining the front pair of fronto-orbitals. There are a few hairs in the space between the frontal triangle, the eyes and the last fronto-orbital bristle.

Face slightly widening to the mouth, somewhat silvery, the prelabrum yellowish on its margin. Jowls about one-fifth the vertical height of the eyes. Two vibrissa on each side and a bristle on the jowl below the eye. Back of head the same colour as the frons. Antenne with first and second joints yellow, third joint brown. Arista with three side and one terminal rays.

Palpi yellow with a few stout black hairs below ; tongue rather horny.

Thorax. Olivaceous with minute granular pollination; chætotaxy as in generic description; scutellum darker but paler at the tip; pleuræ dark grey, slightly shining, hairy on the meso-pleura and about seven hairs on the sterno-pleura, three in a horizontal row at the top and four in a vertical row from the mid-point. Metanotum somewhat shining, silvery grey.

Wings glassy with yellow veins, costa ciliated with fine closely-packed black hairs, stouter on the first section.

Halters pale.

Legs. Coxre yellow; femorn all dark brown-grey except the knees; tibire suffused; tarsi yellow except the last joint in hind and middle and last two joints in front legs. All the legs clothed with short bristly hains; a longer row below the front femora; a stout spine at the end of the middle tibic. The hairs on the tarsal joints are exceptionally evident.

Abdomen. Shining brown-black, the last segment being the darkest; the distal margins of the segments are very narrowly lined with a paler tone. Dorsum covered with bristly hairs, the marginal ones longer: the last segment has some eight still longer bristles, which stand out more nearly perpendicular to the surface.

Size. $2 \frac{1}{3} \mathrm{~mm}$.

Loculity. Seychelles. Malré : from seaweed on beach at Anonyme Island, I. 1909.

\section{Paralimna, Loëw.}

Paralimna Loëw, Monograph of the Diptera of N. America, i. (1862), p. 138.

17. Paralimna linenta De Meijere, Tijdschr. voor Entom., li. (1908), p. 165.

This species was described fiom Semarang: the specimens from the Seychelles agree closely with the description.

Localities. Seychelles. Mahé : from marshy ground just behind the beach at Port Glaud, 5. XI. 1908; marshy ground near sea-level at Cascade, 20. II. 1909. 
HeCa Mede, Haliday.

Hecamede Haliday, Ann. Mag. Nat. Hist., ser. 1, iii. (1839), p. 224.

18. Hecamede lacteipennis, n. sp.

This is a very distinct and brightly-coloured species.

Head (Pl. 15, fig. 15). Frons with a large grey triangle extending to the lunula, eye-margin grey, the rest of frons orange-yellow: this colour thus forms two triangles pointing backwards from the front margin: the lunula is whiter. The bristles are as follows: inner and outer verticals, a pair of bristles just behind the line joining the hind ocelli, two other pairs near the margin of the triangle, the pair nearer the back of the head being about half-way down the triangle, the other pair half-way between the former pair and the point of the triangle; in addition the triangle has some dozen bristly hairs of which two form a distinct pair just at the tip of the frontal triangle. There are two pairs of fronto-orbital bristles, the front pair bent forwards, the other backwards. The face is silvery white with a distinct suture running up each side to meet the margins of the lunula: just along the side of this suture is a row of three vibrissæe, the top ones standing on a very small hillock; the facial knob is small, shining and very prominent.

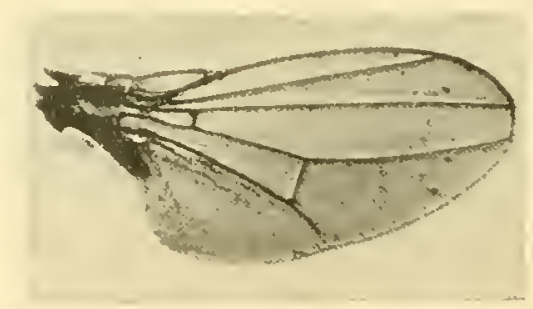

Fig. 9. Hecamede lacteipennis, no sp., wing.

The jowls are shining silvery and have only one or two fine bristles instead of the many bristles of $H$. albicans; the tongue is reddish-yellow with its bent tip only about half the length of that of the latter species. The palpi are pale yellow.

Antennæ as in $H$. albicans, with pale yellow second joint and slightly darkened third joint; arista short with four side and one terminal rays.

Thorax. Similar in form to $H$. allicans but is pale grey in colour like the abdomen of that species; its surface and that of the concolorons scutellum is uniformly covered with short stout bristly hairs; chæetotaxy normal including the six scutellar bristles.

Wings as Fig. 9, white, with perfectly pale veins.

Halters yellow.

Legs yellow except the femora which are rather dark silvery grey; the last tarsal joint somewhat suffused. 
Abdomen concolorous with thorax, except that the base is often slightly reddish; dorsum with sparse scattered bristles, those on the last two segments being longer.

Size. 2 to $2 \frac{1}{2} \mathrm{~mm}$.

Localities. Astove Island: 1907 (Thomasset). Coetivy: 24. IX. 1905. Seychelles: Mahé, from seaweed on beach at Long Island, VII. 1908.

\section{Mosillus, Latreille.}

Mosillus Latreille, Hist. Nat. Ins. et Crust., xiv. (1804), p. 389.

19. Mosillus albipennis Loëw, Stettin. Ent. Zeit., viii. (1848), p. 14.

This species is recorded from S. Europe, Egypt and Teneriffe. The Cambridge Collection contains several specimens from Durban, Natal.

Locality. Seychelles. Mahé : one specimen fiom Anonyme Island, I. 1909.

Enchastes, 11. g. (PI. 15, fig. 21).

A single specimen (in excellent condition) of a new genus near Mosillus was in the collection; though but a single specimen is available it is thought best to give a full description of the proposed genus, as the insect is of considerable interest. The genus Mosillus was long considered to be in the Chloropidæe, but was finally placed among the Ephydridie from the presence of certain structural details, although the general facies is very strongly that of a black Chloropid. The present insect is similar to Mosillus in many important respects but is more Ephydrid in form and is of a dull green surface which is slightly shagreened, recalling the texture of Pelina.

Head. Eyes bare, long, ovil with axis vertical; jowls deep. Antennæe with rounded third joint, which is but little larger than the second; the basal bristle on the second joint is minute though evident. The top fronto-orbital bristles are small and in line with the front ocellus, the other fronto-orbitals are reduced to hairs. Small inner verticals and a pair on the frons just beyond the front ocellus. 'The most striking difference between Mosillus and Enchastes is best seen on a front view (Pl. 15, fig. 22). In Mosillus the sutures extending from the ends of the lunule each side and separating the face from the cheeks are very nearly parallel; the eyes are round; hence the cheeks widen greatly from the antennal level downwards. In the present genus these sutures diverge somewhat; the eyes are long-oval and hence the cheeks are much more nearly of constant breadth from the antennal level downwards.

The face is protuberant and has a large oblong shining knob: the four facial bristles stand on extremely minute hillocks. The prelabrum is very protuberant and is rectangular or spade-like in profile.

Thorax and scutellum, dorsum with the surface minutely granulate and covered with short bristly hairs instead of the fine hairs of Mosillus. The last pair of dorsocentral bristles, a single notopleural bristle just before the wing base, two mesopleural which are not very strong, two scutellars crossed at the tip. The scutellum is rounded at the tip. Wings and legs much as in Mosillus.

Type, the following species.

SECOND SERIES-ZOOLOGY, VOL. XV. 
20. Enchastes scotti, n. sp. (Pl. 15, fig. 21).

Head (Pl. 15, fig. 22). Form etc. as described and figured for the genus; frons dull dark grey, a frontal triangle is demarcated by two rows of tiny bristles. Eye-margins narrow and more silvery.

\section{Antenne orange red.}

Face shining grey with four bristles each side pointing to the centre line and a few other scattered ones; facial knob extremely shining. Jowls and back of head rather silvery. Prelabrum horny, shining with silvery sides and central spot; tongue coriaceous, the palpi are hidden.

Thorax and scutellum blackish with a fine faintly greenish granulation and black bristles.

Wings with venation as figured with third and fourth veins convergent at the end ; veins pale.

Halters orange.

Legs: femora and tibia dark black-grey with orange knees and tarsi except the last joint. The middle femora with stronger bristles in front.

Abdomen shining black-grey slightly suffused with reddish at the base; second, third and fourth segments increasing progressively in breadth, fifth pointed, pollinated and more hairy than the others.

Size. Just mder $3 \mathrm{~mm}$.

Locality. Seychelles. Mahé : from seaweed on beach at Anonyme Island, I. 1909.

Discomyza, Meigen.

Discomyza Meigen, System. Beschr., vi. (1830), p. 76.

21. Discomyza similis, n. sp.

This species is allied to the Palrearctic D. incurva Meigen, from which it differs in many points but most markedly in the breadth relative to the length. It is about as long as $D$. incurve but is proportionately more slender than that insect; the ratio of maximum thoracic breadth to length measured from the scutellar junction to the front margin is slightly greater than $1 \frac{1}{3}$ in $D$. incurva, while in the new species the ratio is about unity: this ratio holds approximately also for the head and abdomen.

The following description is based principally on the differences between $D$. simitis and $D$. incurva.

Head. The frontal triangle is proportionately larger and is somewhat wrinkled or rugose instead of being flat and shining. The face is similarly knobbed on each side below the antenna, but just below these there are from six to eight small circular pits instead of a shining triangle. Antenna black, the third joint slightly suffused with grey instead of the second joint being extensively bright red, the arista is six-rayed: the chatotaxy is the same, but the bristles are longer and less stout. Correlated with the greater ratio of length to breadth the face is more rounded in ontline. 
Thorax slightly greyer in tone with the scutellum more pointed, and not abruptly cut across.

Wings, as Fig. 10, with blackened costa.

Halters pale yellow.

Legs the same, front pair all black, middle and hind black except for the bright red first to fourth joints to the tarsi.

Size. Most specimens are from 3 to $3 \frac{1}{4} \mathrm{~mm}$, but one measures only $2 \frac{1}{4} \mathrm{~mm}$.

Localities. Seychelles. Mahé: from marsh just behind beach at Port Gland, 5. XI. 1908; Anonyme Island, I. 1909 ; marshy ground near sea-level at Cascade, 20. II. 1909 ; marshes on coastal plain, Anse aux Pins and Anse Royale, I. 1909.

\section{Ilythea, Haliday.}

Mythea Haliday, Ann. Mag. Nat. Hist., ser. 1, iii. (1839), p. 408.

Two species of this interesting genus were collected, but unfortunately the specimens were not in first-rate condition so that very full descriptions camnot be given.

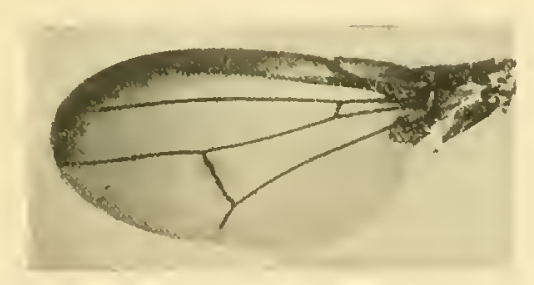

Fig. 10. Discomyza simitis, n. sp., wing.

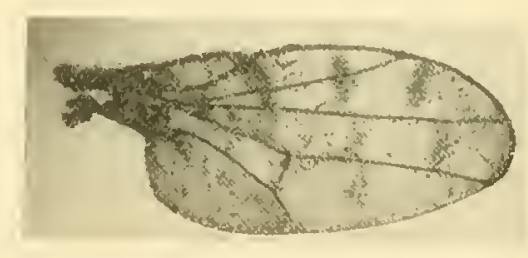

Fig. 11. Ilythea fractivirgata, n. sp., wing.

\section{Ilythea fiactivirgata, n. sp.}

Head. Profile very like I. spilota Curtis, except that the back of the head behind and below the eyes is not quite so swollen. Chætotaxy the same but the bristles less strong. Antennæ similar, but the third joint slightly smaller and the five aristal rays proportionately longer. In top view the head is not quite so flattened, and in front view the shining elongate central knob does not extend so far down to the mouth-margin.

The frons is shining, while the face, jowls and lower eye-margins are dusted with grey. The palpi are long, thin and pale with a few bristles near the end ; tongue yellow with a bent-back tip.

Thorax. Dorsum and scutellum shining blue-black, slightly dusted: as far as can be seen the chætotaxy is normal, but the bristles are again proportionately weaker.

Wings as in Fig. 11, with remarkable interrupted blackish transverse bands, three in number:

Halters yellow.

Legs all yellow. 
Abdomen black and shining, otherwise like that of I. spilota.

Size. $1 \frac{1}{4} \mathrm{~mm}$.

Locality. Seychelles. Mahé: from marshy ground near sea-level at Cascade, 20. II. 1909 .

\section{Ilythea invenata, n. sp.}

This species is very close to the last as regards its main characters. The characters of head, thorax, etc. are practically the same, the principal difference being the reddish colour of the facial dusting, the longer scutellar bristles, the more orange-yellow legs with the firont coxie nearly black.

Wings (Fig. 12). These offer a very striking peculiarity inasmuch as the cross veins are absent: the picture on the wings is more like that of the typical species.

Four specimens of this new species are in the Cambridge Collection and were sent by Mr F. Muir fiom Durban.

Sizc about $1 \frac{1}{4} \mathrm{~mm}$.

Locality. Seychelles. Mahé: marshes on coastal plain, Anse anx Pins and Anse Royale, I. 1909.

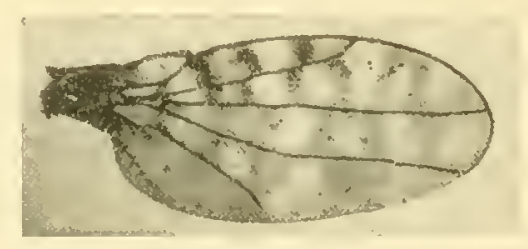

Fig. 12. Hythea invenata, n. sp., wing.

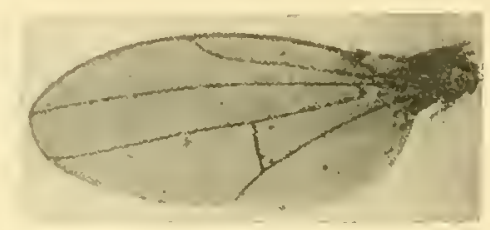

Fig. 13. Psilopa nitidissima, n. sp., wing.

Psilopa, Fallén.

Psilopa Fallén, Dipt. Suec., Hydronyz., (1823), p. 7.

24. Psilopa nitidissima, n. sp.

This species is very closely related to the Palearctic species $P$. compta Meigen; it is however much more shining, being brilliant green with coppery or purplish reflections instead of pure green. In the description given comparison is made with $P$. compta.

Head similar in form, ehretotaxy etc. including the antennæ, except for being brilliantly shining.

Thorax. Similar; scutellum more swollen at the sides, the flattened part of disc smaller, and the whole somewhat smaller in proportion and more rounded in outline.

Wings (Fig. 13) differ in that the second vein is shorter.

Legs; differ in that the tibire are all blackened in the middle.

Abdomen, very shining, the distal part is red-coppery in colour.

Size. $2 \mathrm{~mm}$.

Locality. Seychelles. Mahé: from marshes on coastal plain, Anse aux Pins and Anse Royale, I. 1909. 
25. Psilopa longicornis, n. sp.

This species is rather aberrant in the genus, but seems best placed there. It is an elongate form with an exceptionally long third antennal joint. Most of the specinens were rather worn, so that slight uncertainty arises in regard to the colours.

Head (Pl. 15, fig. 16). Frons and vertex greenish brassy with grey pollination, the broad eye-margins more brassy but not truly shining: a well-marked straight lunular suture crosses the frons just above the antenna and extends from one eye-margin to the other. Below this the fice is pollinated like the frons. The pollination is frequently rubbed off, when the ground colour beneath is seen to be reddish bronze. Jowls silvery; prelabrum often showing slightly, shiny, and horny in texture. Inside of mouth and the palpi yellow; tongue stont and yellowish grey.

The usual pair of fronto-orbital bristles inserted side by side, strong, the immer pointing backwards the outer forwards; inner and onter verticals; very long ocellars; stont vibrissæ, and the usual stout long bristle on the hind head just below the back of the eye.

Antenn blackish with yellow tone, the basal joints being somewhat silvery; the curved bristle on the second joint is fairly long but fine; third joint very long, arista long pectinate with eight side rays and one terminal.

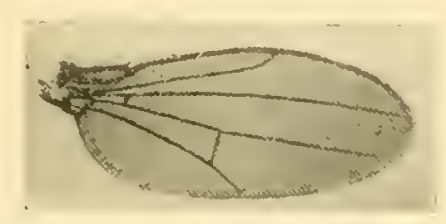

Fig. 14. Psilope lonyicornis, n. sp., wing.

Thorax. Shining greenish with grey pollination; a well-marked more brassy central line, each side of this being well pollinated. The dusting is easily knocked off, and many specimens were bare. One pair of dorso-central bristles, scutellum dusted like the thorax, a pair of terminal bristles and the usual pair near the base are especially long and stont.

Wings (Fig. 14); veins yellow.

Halters, knob whitish and stalk yellow.

Legs yellow with very slightly darkened femora.

Abdomen, dark greenish black, slightly pollinated with the basal part of the dorsum often yellowish in the centre; the whole is covered with stout bristly hairs, longer on the margins of the segments.

Size about 2 mm.

Loculities. Seychelles. Mahé: marsh just behind beach at Port Glaud, 5. XI. 1908 ; marshes on coastal plain, Anse anx Pins and Anse Royale, I. 1909. 


\section{Altotrichoma, Becker.}

Allotrichoma Becker, Dipterolog. Studien, iv., Berlin. Ent. Zeitschr., xl. (1895), p. 121.

Some 14 specimens of an insect were collected which seems to be best placed in this genus. The male agrees with Becker's generic characters and possesses peculiar genitalia like those figured by him (l.c., Plate IV, figs. 7, 8). The female is extremely like a Discocerina and in both sexes the form and colour bear a strong resemblance to those of a nember of that gemus.

26. Allotrichoma argentiprotexta, n. sp.

Shining black like a Discocevina, covered with fine sparse golden pollination.

Head (Pl. 15, fig. 20). Vertex and frons shining black, no well-marked frontal triangle, in good specimens the pollination is evident. Face rather silvery, with a wellmarked silvery line above the mouth extending round the lower eye-margin; prelabrum exserted, shining blackish.

Antenne black, arista thickened at the base with four side rays, shortening from the base to the tip, and one terminal ray; a well-marked bristle on the second joint.

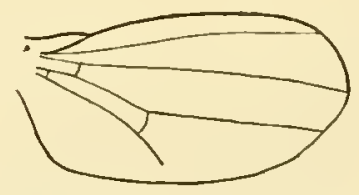

Fig. 15. Allotrichoma argentipretexta, n. sp., wing.

Face with two well-marked side bristles; the usual chætotaxy, backward and forward orbital pair, ocellars, inner and outer verticals, strong forwardly directed post-verticals as strong as the ocellars.

Thorax with fine achrostical and other similar fine bristles each side of them on the dorsum. Scutellum rounded and slightly arched with four bristles.

Wings as Fig. 15 with dark veins.

Halters white.

Legs dark brown with the first joints of the tarsi light brownish yellow, last joints slightly suffused.

Abdomen of. Third segment about twice as long as the second; fourth pointed, nearly as long as the previous two; fifth very tiny or drawn beneath. Hypopygium with appendages shaped like small pale flattened strips of nearly uniform width, not spatulate as shown in Becker's paper (l.c. Plate IV, fig. 7), two stout divergent hairs on the end and a finer central hair, and a few various sized hairs along the side.

q. Five segments visible, each a little longer than the previous, the fourth greater than third and third greater than second; rounded visible fifth segment, abdomen covered with fine hairs. 
Size (excluding antenna) about $1 \frac{1}{2} \mathrm{~mm}$.

Localitics. Seychelles. Silhonette: low coconut-planted country near the coast, Pointe Étienne, 17. IX. 1908. Mahé : marshes on coastal plain, Anse aux Pins and Anse Royale, I. 1909 ; near Morne Blanc, about 800 ft., X-XI. 1908 ; Cascade Estate, about $1000 \mathrm{ft} ., 1908-9$; Anonyme Island, I. 1909.

\section{Hydrellinæ.}

Hydreltis, Robineau-Desvoidy.

Hydrellia Robineau-Desvoidy, Essai sur les Myodaires, v. (1830), p. 790.

A single species of this genus was found which $\mathrm{Mr}$ J. E. Collin informs me belongs to the griseola group.

27. Hydrellia varipes, n. sp.

A black insect with variegated legs.

Head. Frons, vertex and back of head black, rather shining, slightly brassy. A bright silver lunule over the antenne. Face closely covered with shining brown-gold pollination with four well-marked fine bristles bordering the eyes. Jowls small, grey as is the lower back of the head, two bristles just below the back lower angle of the eye and a few scattered ones behind it. Palpi yellow, antennæ black with nine side rays and one terminal.

Thorax, shining black with greenish tone: two pairs of dorso-centrals, the front pair very near the cross suture, continued forward by a few small bristles. Achrostical bristles in two rows, fine. Scutellum as thorax, flattened on the disc, two terminal and two basal bristles with two fine side hairs between. Pleure and metanotum grey.

Wings normal in venation with brown veins.

Halters, bright yellow knobs with somewhat darkened stalks.

Legs: front, coxie yellow but slightly darkened at the base in front; trochanters yellow; femora black with extreme tips (at each end) yellow; metatarsus yellowish, other tarsal joints black but just perceptibly spotter with yellow at the extreme distal tip. Other legs as front but coxa and trochanters slightly suffused and the hind metatarsi brighter yellow.

Abdomen; black, less shining than thorax, bristly, the marginal bristles being especially distinct; segments of nearly equal length.

Size about $1 \frac{3}{4} \mathrm{~mm}$.

Localities. Seychelles. Mahé: marshes on coastal plain, Anse aux Pins and Anse Royale, I. 1909 ; cultivated and marshy country near sea-level at Cascarle, 20. II. 1909 ; cultivated country about 1000 ft., XI-XII. 1908; near Morne Blanc, about $800 \mathrm{ft}$., X-XI. 1908. 
Philygria, Stenhammar.

Philygria Stenhammar, Ephydr., (1844), p. 238.

28. Philygria striata, n. sp.

A single specimen was captured which is superficially much like a small $P$. picte Fall., with which the species is compared in the description. It has the same two silver thoracic stripes and silvery eye-margins.

'The differences are as follows:

Head. The third joint is much smaller, pointed, a little longer than broad, slightly hairy at the top ; the aristal rays are much finer and less regular and pale instead of black; the first two-fifths of the arista is rery thick and then suddenly thins out for the remainder. The mouth is less prominent; the lower eye-margins are proportionately a little wider. Two vertical bristles and the ocellars present but finer.

Thorax. The silvery stripes are a little wider, and the dorsum of the scutellum is the same colour as the disc of the thorax, not deep dull black: the silvery side spots to the scutellum are present.

Wings; the second vein is longer and all the reins thinner and paler.

Halters like picta with long whitish heads.

Legs entirely pale yellow with no infuscation.

Abdomen the same, but the anal half is not quite so shiny and the third segment bears two small dusty spots.

Size. $1 \mathrm{~mm}$.

Locality. Seychelles. Mahé: marshes on coastal plain, Anse aux Pins and Anse Royale, I. 1909.

\section{Phitygnive sp. ?}

There are two imperfect specimens gummed on card which belong to the picta group. It is impossible to give any description owing to the condition of the specimens.

Loculity. Seychelles. Mahé : marshes on coastal plain, Anse aux Pins and Anse Royale, I. 1909.

\section{Ephydrinæ.}

PARYdra, Stenhammar.

Parydra Stenhammar, Ephydr., (1844), p. 144.

The single species of this gemus is somewhat aberrant in that it has a pointed antenna and teeth on the front femora; in appearance it is nearer to $P$. pusilla Meig., than to the other more normal members of the genus.

30. Parydie tuberculifera, n. sp.

Head (Pl. 15, fig. 18). Frons, vertex and back of head shining black obscured with yellow pollination on the back, slightly so on the eye-margin and above the antennæ. In 
top view the head is mainly of excessively shining black which forms an area bounded forvardly by the pollination over the antenne and sideways by the eye-margins, but extending in a triangular shape from the vertex almost down to the neck where the boundaries are formed by two elongate excessively pollinated patches. The ocelli are nearly in the centre of this shining area. The face and jowls are also shining black with a neatly distributed sparse white pollination; in front view this invades the frons above the antenno. Hind head swollen as are the eye-margins except just at the centre of the hind margin of the orbits. The sides of the head behind are also well pollinated. 'Tongue with dark grey chitinous basal part clothed below with fine white silky hairs, the distal part horny, the tip with a few small teeth. Palpi linear, yellow. Antenne black, the arista thick for the first two-fifths, of the next portion the proximal half is finely pubescent on the top and the distal half is bare; third joint oval with a remarkable pointed tip.

Chretotaxy normal; two fronto-orbital bristles, ocellars, inner and onter verticals; a fine but long bristle projects from each side of the facial eye-orbit and is succeeded by side rows of eight to ten fine hairs along the lower eye-margins; the projecting prelabrum is the same colour as the face.

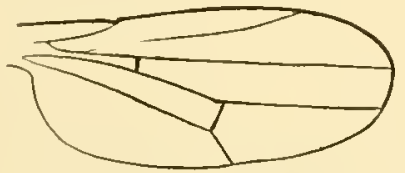

Fig. 16. Parydra tuberculiferu, n. sp., wing.

Thorax and scutellum shining black with a very neat sparse yellow pollen, two shining patches over the wings and each side of the base of the scutellum. One pair of dorso-central bristles, other bristles normal but the achrosticals very fine and indistinct; pleura grey owing to pollination.

Wings as Fig. 16, finely ciliated all round the margin, thicker on the first costal segment; veins brown; no paler or transparent "windows" or patches present.

Halters orange.

Legs bright orange yellow, except the last tarsal joints which are black and finely haired, the hairs being stronger on the hind tarsi and on the last joint of the other tarsi. Front femora with a row of tubercles starting at the centre (Pl. 15, fig. 17), where the femur is thickened, and forming a row of blunt saw-teeth from there up to the insertion of the tibia ; between the tubercles are fine hairs; middle femora ciliated below.

Abdomen. Shining black with sparse pollination; the margins of the segments paler, yellowish and less shining.

Size about $2 \mathrm{~mm}$.

Locality. Seychelles. Mahé: marshy ground near sea-level at Cascade, 20. II. 1909. 


\section{Scatella, Robineau-Desvoidy.}

Scatella Robinean-Desvoidy, Essai sur les Myadaires, iii. (1830), p. 801.

A single species occur's which is characterised by the seven distinct "windows" on the wing.

31. Scatella septemfenestrata, n. sp.

Head. Profile like S. stagnalis Fall., but the facial knob is somewhat more prominent. Frons and vertex shining black dusted, two fronto-orbitals; face dusted with grey pollen, a strong bristle each side above the mouth margin. Back of head and jowls black with grey pollen, a strong bristle on the jowl below the eye. Antenne black.

Thorax densely covered with red-brown pollen; when rubbed the ground is seen to be shining black. Scutellum with two terminal bristles and two side hairs.

Wings as Fig. 17, tinted brownish with seven windows which appear as whitish patches on side illumination, two are between the second and third veins, the distal one being the fainter, three between the third and fourth veins, the distal one being the fainter, the two others lie one each side the cross vein between fourth and fifth. None of these spots are very large nor do they appear to push the veins apart.

Halters pale whitish yellow.

Legs entirely black.

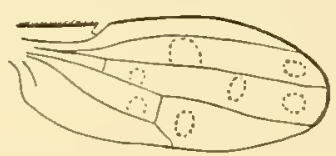

Fig. 17. Scatella septemfenestrata, n. sp., wing.

Abdomen. Like the thorax with equal segments.

Size about $1 \frac{3}{4} \mathrm{~mm}$.

Locatity. Seychelles. Mahé: from marsh just behind beach at Port Glaud, 5. XI. 1908.

\section{Canace, Haliday.}

Canace Maliday, Ann. Mag. Nat. Hist., ser. 1, iii. (1839), p. 411.

One specimen of a new species of this interesting genus was collected on the seashore of Mahé. It differs considerably from either of the two European species, being nearer to $C$. nasica Hal. than to $C$. ranula.

32. Canace mahensis, 11. sp. (Pl. 15, fig. 19).

The insect is of a uniformly dark grey colour, more silvery on the pleuræe and legs and with a silvery face and labrum.

9. Head. In profile longer than high, while in C. nasica it is the other way, this is partly due to the smaller jowls. There is a well-marked depressed frontal triangle and a large facial knob just touching the base of the antennæ. Eyes longish oval, with the major axis nearly horizontal, small. 
The bristles are as follows: three stout outwardly overhanging fronto-orbital bristles, inner converging verticals and outer somerwhat finer verticals, no true post-verticals; an ocellar pair midway between each basal ocellus and the front one; another pair of bristles in front of these, each about midway between the true ocellar bristles and the forward frontoorbital bristles. The ocelli are musually wide apart and form an equilateral triangle.

The silvery jowl bears three bristles about equally spaced, the lowest is below about the middle of the eye and half-way dow the jowl, and points downwards and forwards, the other hind two point somewhat upwards; on viewing the face in profile the frontoorbital and jowl bristles converge towards one another to form a sort of cage to protect the eyes. The facial bristle of $C$. nosica is absent. The antenns are much as in that species, black, with a fuintly pubescent arista.

The silvery labrum is visible; tongue large and fleshy.

Thorax. The chætotaxy is as in C. nusica, but the four dorso-central bristles and the marginal bristles are proportionately longer and more striking. Otherwise the dorsum is absolutely bare and smooth, contrasting with the bristly dorsum of $C$. nasica. The scutellum has fou bristles, the terminal ones directed upwards, the two basal ones backwards, but it lacks the small dorsal pairs. The pleural bristles are destroyed by the pinuing of the specimen.

Wings and halters as $C$. nasica.

Legs: fiont femora have a row of five fine long bristles, and the middle and hind femora are slightly spiny in front; hind femora in no way thickened.

Abdomen. Narrow and long but segmented as in C. nasica; two processes on the dorsal side for holding the egg as shown in the figure. 'The preceding segment has the pair of long bristles.

Size about $1 \frac{3}{4} \mathrm{~mm}$.

Locality. Seychelles. Mahé: from seaweed on beach at Long Island, VII. 1908. A second badly preserved specimen is among some material from Coetivy.

\section{Chloropidae. Chloropinae.}

Ops, Becker.**

Ops Becker, Ann. Mus. Nat. Hung., viii. (1910), p. 402.

33. Ops glaberrima, n. sp. (Pl. 16, figs. 1-4).

f, ㅇ. This species must be near Chloropisca callichroma Loëw from Africa, but differs therefrom in several essential points.

Head (Pl. 16, figs. 1, 2). The frons and face are of equal width, the eye-margins being parallel and equidistant from the vertex to the mouth. The vertex and frous are bright yellow with a small black shining vertical spot. The vertical "triangle" (Pl. 16 , fig. 2) is very shining and extends fiom the vertex (where it nearly fills the space from

* 'This name is preoceupied in the Lycaenidae; see de Nicéville, Journ. Bombay Nat. Hist. Soc., vol. ix. 1895, p. 296. 
eye to eye) to close up to the base of the antenne: the front edge terminates in a slightly curved line which covers one-third of the frontal breadth; the side margins are slightly concave.

Note. When the specimen is shrivelled the shape of the frons etc. has a somewhat different appearance: the central strip of the frons is more strongly chitinized than the spaces between it and the eyes; on drying this central strip falls in and drags the side strips down with it so that the frons appears to be deeply furrowed; the bottom of the furrow being the central strip, the side strips now form roughly perpendicular boundaries of the furrow. When this occurs the eye-margins no longer appear paralle] throughout.

The face is yellow slightly dusted with silver, with two very shallow antennal fover: the mouth opening when viewed perpendicularly to its plane is trapezoidal in outline; the upper lip is pale, the sides of the mouth edge are margined with a fine brown line; palpi and tongue reddish brown.

Antemæ reddish yellow with a brown slightly pubescent arista.

Back of head black with a broad yellow margin all round; jowls very small.

Thorax (Pl. 16, fig. 3). Dorsum shining black with a somewhat irregular contour, having a nick at the cross suture, and a slightly wavy and less sharply defined hind margin. The black central part is bordered with bright yellow; pleura yellow with a reddish linear spot just behind the cross suture and an elongated black spot on the same.

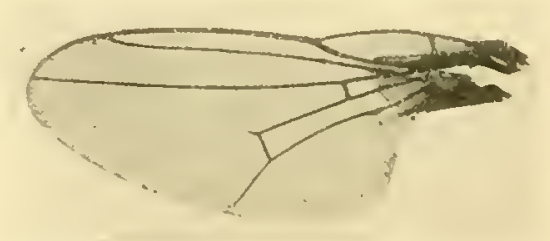

Fig. 18. Ops glaberrima, n. sp., wing.

Scutellum in the form of a nearly equilateral triangle with rounded angles: very flattened on the dorsum; a pair of short black converging terminal bristles; metanotum shining black.

Wings (Fig. 18): venation normal, the distal part of the fourth vein being much less distinct than the other veins; extreme base of costa blackish and slightly swollen.

Halters with briglit canary yellow knobs, stalks blackened beneath.

Legs pale yellow including the tarsi, which have minute black claws.

Abdomen. First and second segments reddish yellow, the latter with the usual two tiny black spots on the extreme margin, sides paler. The third shining black including the sides to the belly. Fourth yellowish with a broad black stripe interrupted in the centre, the breadth of stripe and interruption varying somewhat in different specimens. Fifth yellow with two elongate black basal side spots, the remainder being pale yellow.

Size. 2 to $2 \frac{1}{2} \mathrm{~mm}$. 
Localities. Seychelles. Mahé: Cascade Estate, about 800 ft., 1909 ; near Morne Blanc, X.-XI. 1908; swept from rank vegetation in marshes on coastal plain at Anse Royale, I. 1909.

Var. dentata, n. var. A pale variety (or sub-species) occurs in which the thoracic black dorsal mark extends less far behind and appears like a central mark with tro backwardly directed side lobes (Pl. 16, fig. 4). 'The abdomen is wholly devoid of black marks, the basal part being reddish yellow, the rest pale yellow.

Loculities. Seychelles. Mahé: Cascarle Estate, about $800 \mathrm{ft.}, 1909$; marshes on coastal plain, Anse Royale, I. 1909.

\section{Oscininæ.}

Gampsocera, Schiner.

Gampsocera Schiner, Wien. Ent. Monatschrr, vi. (1862), p. 431.

A single specimen of an insect was obtained which seems best placed in this genus. The specimen agrees with Schiner's generic characters with the exception of the shape of the scutellum: Schiner's description says, "Rückenschild flach gewölbt, am Rande beborstet, Schildchen verhältnissmässig klein." Becker (Archivum Zoologicum, Vol. i. no. 10, p. 117) defines the genus and figures the head of $G$. scutellata Heeger"; he clescribes the scutellum as "halbkreisformig." The present specimen agrees with his figure as to the shape of the head and antenne, but the scutellum is elongate as shown in Pl. 16, fig. 5. In other respects the agreement with the published generic character is close.

34. Gampsocerce scutellata, n. sp.

3. Head. The shape is very like Becker's figure (l.c. Plate III, fig. 68) but the bairy eyes are not rounded at the lower inner edge, the margin being there angulated. Frons black; the triangle large, shining black, the base nearly tilling the space between the eyes; it extends to the base of the antenne. The antennæ lave the third joint less pointed than in Becker's figure (l.c. Plate III, fig. 69), being more nearly kidney-shaped: the second and third joints are yellow. The black apical arista is flattened in section and very densely pilose, its two joints being quite distinct, the last ends in a distinct though fine terminal bristle. The proboscis and palpi of the single specimen are completely retracted.

Thorax (Pl. 16, fig. 5). Shining black on the dorsum and pleuræ. The former is finely punctate and clothed with delicate white hairs; there are no dorsal bristles. The scutellum has a blunt-pointed triangular outline (Pl. 16, fig. 5) and is strongly arehed and more coarsely punctate than the thorax. It is black with two strong divergent terminal bristles: the dorsum and sides have small white bristly bairs.

Wings immaculate, yellow at their insertion; the venation is as figured by Becker (l.c. Plate III, fig. 70), except that the second vein bends more sharply up to the costa which it meets about midway between the ends of the first and third veins.

Halter's yellow.

Legs entirely pale yellow. 
Abdomen. Basal part orange-yellow, the rest (inclnding the venter) shining black. Size. $1 \frac{1}{2} \mathrm{~mm}$. exclusive of antennæ.

Locality. Seychelles. Mahé: marshes on coastal plain, Anse anx Pins and Anse Royale, I. 1909.

\section{Anatrichus, Loew.}

Anatrichus Loëw, Öfvers. Kongl. Vet. Akad. Förhandl., xvii. Dipt. (1860), p. 97.

35. Anatrichus arenaceus Loëw, l.c. 97. 13.

This insect has a wide distribution in Africa; it is known from South Africa, Egypt, the Chirinda forest, ete.

Locality. Seychelles. Mahé: the collection contains six specimens from the marshes on the coastal plains of Anse aux Pins and Anse Royale, I. 1909.

\section{Meroscinis, De Meijere.}

Meroscinis De Meijere, Tijdschr. voor Entom., li. (1908), p. 172, Pl. 4, fig. 14.

This genus was established by De Meijere for a Chloropid from Semarang, Batavia. Becker records two species from Africa in the Anm. Nat. Mus. Hung. (1910). There are two species from the Seychelles which can be referred to this genus.

36. Meroscinis ceneifrons, n. sp.

The colour is uniformly shining black except that the first two or three tarsal joints are bright yellow and that the third antennal joint is very slightly rufous, especially on the inner side.

Head (Pl. 16, figs. 6, 7). The vertical triangle is large, shining metallic blue; it extends to the front antemnal margin where it is abruptly cut off (Pl. 16, fig. 7). The fronto-orbital bristles are strongly developed, and there is an inner row of strong bristles bordering the shining vertical triangle. The former are slightly bent backwards, the latter forwards and arching inwards towards one another. The post-ocellar pair are crossed; the outer vertical pair strongly developed. The mouth-margin is bristled.

Antennæ with an orbicular third joint with a strongly pubescent brownish-black arista.

Eyes bare.

Tongue and palpi black.

Thorax. Shining black, finely punctate and covered with short pale hairs: the single post-alar bristle is fiirly strong, the others very small or absent. Pleura shining black and slightly rugose. Scutellum shining greenish-black, more densely punctate than the thorax, the punctation being coarser : it is also covered with pale silky hairs ; two long terminal bristles, much divergent and about as long as the scutellum.

Wings with venation as shown in Fig. 19: glassy with black veins.

Halters with black heads but yellowish stalks. 
Legs black except for very indistinctly paler knees, the first two joints of the front tarsi and the first three joints of the middle and hind tarsi which are yellow.

Abdomen. Entirely shining black with black hairs.

Size. 2 to $2 \frac{1}{2} \mathrm{~mm}$.

Locrelities. Seychelles. Silhonette: Mare aux Cochons, platean and forest above, VIII.-IX. 1908. Mahé : Cascade Estate, about 1000 feet, 1908-9.

37. Meroscinis rugose, n. sp.

This differs from the last species as follows:

Head (Pl. 16, fig. 8). The shining triangle is not so strongly blue and is pointed at the end. The antennal joints are bright yellow-red with the arista paler and finely pubescent.

Thorax. The punctation of both thorax and scutellum is coarser', that of the latter being unusually coarse: the scutellum has a purplish tone of colour and a blunter tip; there are four scutellar bristles, the terninal pair being situated on small but noticeable papillie, the two smaller side ones being also on papillie which are, however, smaller.

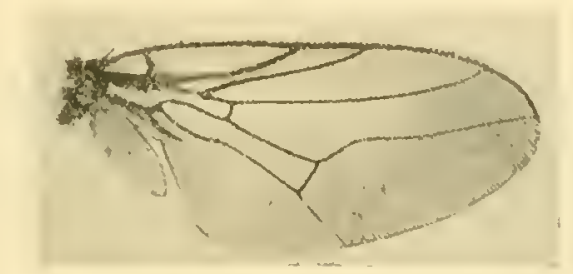

Fig. 19. Meroscinis ceneifrons, n. sp., wing.

Wings with pale veins.

All the legs have yellow trochanters, black femora with yellow knees, yellow tibiæ with a broad black or blackish ring round the middle, and entirely yellow tarsi.

Size as last species.

Loculities. Seychelles. Mahé : Cascade Estate, about 1000 feet; marshes on coastal plain, Anse aux Pins and Anse Royale, I. 1909.

\section{Hippelates, Loew.}

Hippelates Loew, Berlin. Ent. Zeitschr., vii. (1863), p. 36.

This genus was founded by Loëw for certain American forms. Becker has described one from Madeira (Archiv. Zool., i. 150), and De Meijere one from Java. Five species occur in the Seychelles, one of which agrees with a published description.

38. Mippelates nigricornis Thomson, Eugenies Resa, p. 607.

Uescribed from Ins. Rossi.

Locality. Seychelles. Mahé : Anonyme Island, I. 1909. 
39. Hippelates stigmatica, n. sp.

This is the smallest of the five species and must be nearly related to $I$. minor De Meijere (Tijd. voor Entom. li. 168). The latter has black thoracic stripes and entirely yellow legs, while the present species has brownish stripes and the whole of the front tarsi and last joints of mid and hind tarsi black. It possesses the pleural spot of $H$. minor.

6ㅇ. Head. Entirely yellow except for a round black spot on which the ocelli stand; the frontal triangle is concolorous with the rest of the frons but is much more shining, its base almost fills up the space between the eyes and its point extends to about halfway between the vertex and the antennal bases. Antennæ yellow with a slightly pubescent black arista. Orbital bristles $(1+3)$, imner and outer verticals, crossed postverticals; a row of bristles along each side of the frontal triangle directed forward and inward; small vibrissæ present. Jowls about one-fourth depth of eye. Tongue and palpi yellow.

Thorax. Yellow-brown; in well-marked specimens there are four longitudinal stripes of darker brown which do not meet either the front or the hind borders of the dorsum; these lines vary somerwat in breadth and in some cases are confluent, especially

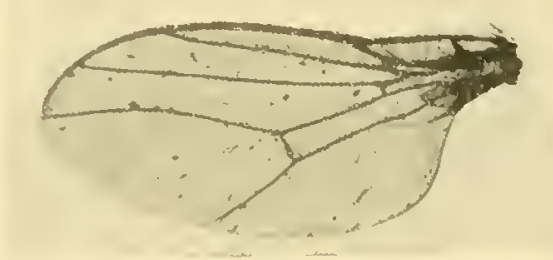

Fig. 20. IIippelates stigmatica, 1. sp., wing.

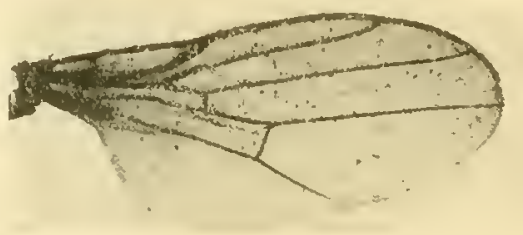

Fig. 21. IIippelates longiseta, n. sp., wing.

in the case of the central pair. The last pair of dorso-central bristles are present, but the bristles are easily damaged. Pleura with a shining black spot. Scutellum pale yellow with two terminal and a few side and discal bristles. Metanotum shining black.

Wings, as in Fig. 20, hairy with yellow veins.

Halters pale whitish-yellow with yellow stalks.

Legs yellow with darkened tip to tibia and dirkened tarsi in first pair; last two joints of tarsi black in other pairs, the tibial spurs of the hind legs are small.

Abdomen. Brownish-yellow : the ovipositor shining black.

Size. About $1 \frac{3}{4} \mathrm{~mm}$.

Localities. Seychelles. Mahé: from near Morne Blanc, abont 800 feet, X.-XI. 1908; Port Victoria, XII. 1908; marshes on coastal plain, Anse aux Pins and Anse Royale, I. 1909; Anonyme Island, I. 1909.

40. Hippelates longiseta, 11. sp.

'This is a very interesting form in which the tibial spurs are greatly developed, and the male possesses a pair of very long fine bristles on the tongue. All the bristles on the insect are pale. 
5, +. Head (Pl. 16, fig. 9). Yellow with a small black ocellar dot; frontal triangle pale shining yellow with its base nearly reaching from eye to eye and its point extending very nearly to the antennæ; face, palpi and tongue yellow. Eyes slightly pubescent. Fronto-orbital bristles $(1+3)$, outer and imer verticals the former divergent, crossed postverticals, strongly crossed ocellars, a row of fine inwardly convergent bristles parallel to but slightly removed fiom the sides of the frontal triangle. Antennæ pale with a large third joint, a brown pubescent arista, aud a strong bristle on the top edge of the second joint.

'Tongue yellow: in the male it possesses a pair of long fine pale seta as shown in fig. 9, the female is devoid of these setr.

Palpi yellow.

Thorax. Dorsum yellowish red: in some cases a pair of brownish red lines run from the last pair of dorso-central bristles (the only pair present) to just behind the humeral calli; these lines vary in intensity in different specimens. The dorsum is covered with pale hairs. Plemra pale yellow; when the insect is viewed perpendicular to its dorsal plane the pleural bristles stand out as long though fine. Scutellum flattened, pale yellow, covered with hairs; four scutellar bristles the end ones long and crossed at the tip.

Wings as Fig. .21; veins pale.

Halters yellow.

Legs all pale yellow. The hind pair are long and the terminal tibial spur is very black and long, being nearly equal in length to the metatarsus.

Abdomen yellow.

Size. $2 \frac{1}{4} \mathrm{~mm}$.

Localities. Seychelles. Mahé: Cascade Estate, about $1000 \mathrm{ft.}, 1908$-9 ; Anonyme Island, I. 1909. Amirantes: Eagle Island, 17. X. 1905. Cargados Islands: Establishment Island, 28. VIII. 1905.

\section{Hippelates nigrescens, 11 . sp.}

This species is similar to the last in form, venation, etc. ; it differs as follows:

All the bristles are black.

Head. Blackish brown, yellow just above the antennæ. Antennæ nearly black. Lower eye-margins silvery. Frontal triangle black and shining, reaching to about two-thirds way down to the antennæ. Eyes very hairy. Tongue devoid of seta in the male.

Thorax with dorsum dark brown, the scutellum yellow. Wings with pale veins. Legs similar to last species but slightly stouter, also with large tibial spurs.

Abdomen black.

Size. $2 \frac{1}{2} \mathrm{~mm}$.

Locality. Seychelles. Mahé : scrubby forest vegetation on summit of Mount Sebert, $1800 \mathrm{ft}$. or more, I. 1909. 
42. Hippelates femorata, n. sp.

A single specimen labelled "Astove 1907 (H. P. 'Thomasset)" differs considerably from the above; it has distinctly incrassated hind femora. The specinen is gummed on a card and hence camnot be fully described; it is so distinct that no difficulty should arise in identification.

․ Head. Frons yellow with black shining triangle; hind head completely black but interrupted on the line of the vertex by two yellow spots one each side of the ocelli. Bristles as in $H$. longiseta, but the crossed post-vertical pair are exceptionally strong.

Eyes bare.

Antennx brownish but no detail can be given as they are buried in the gum.

Thorax. Dorsm black with the central part yellowish the yellow part extending from about the cross suture to the scutelhum. The humeri are swollen and yellow with a small brown dot in the centre of each. Pleura yellow. Scutellum black, flattened, punctate, with two long couvergent black terminal bristles.

Wing very like Fig. 21.

Halters yellow.

Legs: front and middle yellow but the details are hidden by the gum; hind legs, femora with proximal third yellow, distal two-thirds black, incrassated; tibire, black flattened broudening from each end, on the inner face abont the middle is a pale grey spot apparently covered with dust; the tibial spine is black and stout about as long as the metatarsus; the tarsi brownish black the joints being rather stont, especially the metatarsus which is fringed inside with a close row of pale hairs.

Abdomen, black, yellowish at the base with narrow yellow margins to the segments. Size. $2 \frac{1}{2} \mathrm{~mm}$.

Locality. Astove Island: 1907 (Thomasset).

\section{Gaurax, Loew.}

Ganax Loew, Berlin. Ent. Zeitschr., vii. (1863), p. 35.

A pair of specimens seem to be best placed in this genus. Loew in his definition of the genus says "setî subterminali plumatâ." The present insect agrees substantially with his generic description except that the arista is distinctly dorsal. Zetterstedt's Oscinis ephippium is now considered to belong to this genus, though the arista can scarcely be considered subterminal. Pending a revision of the species it appears best to place the present insect in the genus.

43. Gaurax seychellensis, n. sp.

f, ․ Head (Pl. 16, fig. 10). Vertex and frons brownish yellow, but pale yellow from the tip of the frontal triangle to the antennæ; frontal triangle dull black with its base not extending to the eye-margins and with the front angle rounded and extending nearly half way to the base of the antenne, the triangle is bordered each side by a row of pale hairs. 
Face, palpi and tongue reddish yellow, the palpi heing stout, fleshy and slightly compressed laterally.

Eyes large, closely but finely haired.

Jowls silvery below the eyes then yellow. A row of fine fionto-orbital bristles extending from the vertex to the antenne, outer vertical pair, post-verticals, parallel pair of ocellars.

Antemne reddish yellow with a large eircular discal third joint and black pulbescent arista which is inserted about the middle of the upper side of the third joint.

Thorax. Dorsum brownish black, shining, but olseured with slight pollination and yellow pubescence. Humerus yellow; a yellowish spot each side of the base of the scutellum. A smill pair of prescutellar bristles. Scutellum rounded, yellow, hairy with two terminal bristles and three marginal ones each side. Pleura shining yellowish with shining blackish spots just above the middle coxa and the base of the wings. Metanotum shining black.

Wings much as in Gaurax ephippium but proportionately broader, the third vein is very slightly bowed instead of being straight.

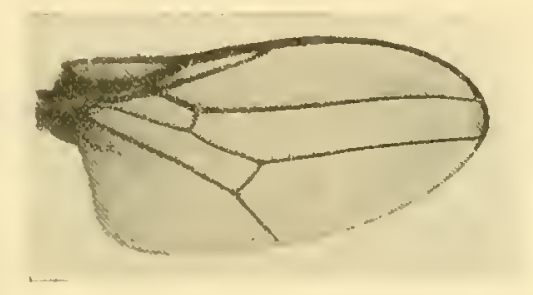

Fig. 22. Siphunculina signata Rond., wing.

Halters and their stalks pale yellow.

Legs pale yellow except for blackened tips to all the femora and a broad blackened ring on the hind tibix.

Abdomen blackish brown, the basal part of the dorsal surface and the venter paler. The female has a well developed soft ovipositor.

Size about $1 \frac{3}{4} \mathrm{~mm}$.

Localities. Seychelles. Silhouette: Mare anx Cochons, IX. 1908. Mahé: Cascade Estate, about $1000 \mathrm{ft} ., 1909$.

\section{Siphunculina, Rondani.}

Siphunculine Rondani, Prodr., i. (1856), p. 128.

44. Siphunculine signata (Wollaston), Ann. Mag. Nat. Hist., ser. 3, i. (1858), p. 117, Pl. V, fig. 8 [Oscinis].

This inseet was described and figured by Wollaston from Madeira. Specimens in the collection agree well with this description and also with that of Becker in the Archiv. Zool., i. (No. 10), p. 132.

The wing is figured (Fig. '20), as Wollaston's figure is not very clear.

Locality. Cirrgudos Islands: Establishment Island and Siren Island, 27-28. VIII. 1905. 


\section{Notonaulax, Becker.}

Notonaulax Becker, Mitt. Zool. Mus. Berlin, ii., p. 153.

45. Notonaulax trisulcata, n. sp.

ઈ, ㅇ. Head. Frons brownish black with a brown antennal margin; quite dull except for a somewhat shining arched line from the ocelli to the eye-margins and an abbreviated pointed mid-line down the small frontal triangle from the ocelli. Face, jowls and palpi yellowish brown; mouth margin and tongue shining black. Eyes pubescent. Antemne with the second joint concolorous with the margin of the frons, the third joint much blackened, arista black and slightly pubescent.

Thorax. Dorsum shining blackish brown, finely haired, slightly dusted, with three deep sulci; the central sulcus is punctate in one uniform row, the side sulci are more widely punctate, the basal part having two rows of punctures side by side; these side sulci increase in breadth from about the level of the cross suture. Pleura same colour as dorsun. Scutellum triangular, slightly flattened, same colour as the thorax, with black hairs:

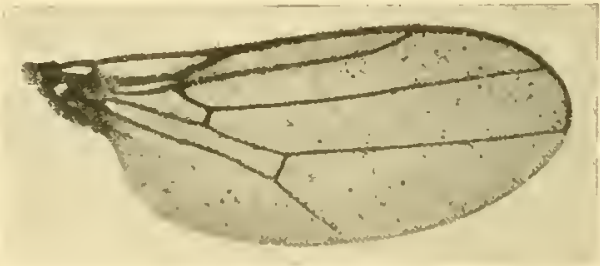

Fig. 23. Notonaulux trisulcata, n. sp., wing.

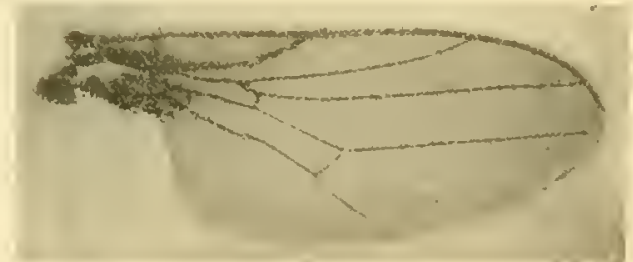

Fig. 24. Oscinis dissimiticonnis, n. sp., wing.

a deep cross groove demarcates it from the rest of the thorax; there are about three short stout marginal bristles on each side, which gradually decrease in size towards the base, and a crossed teminal pair.

Wiugs (Fig. 23) with dark brown veins.

Halter's yellow.

Legs yellow with slightly infuscate hind femora; the hind tibir have on the upper. side a peculiar dusty "brand" on the middle line like that mentioned in $H$. femorata; it is situated on about the middle third.

Abdomen, either concolorous with the thorax or somewhat lighter at the base ; it is clothed with fairly long hairs.

Size. $2 \frac{1}{4} \mathrm{~mm}$.

Locatities. Seychelles. Silhonette: high forest, $2000 \mathrm{ft}$., VIII.-IX. 1908; Mare aux Cochons and forest above, IX. 1908. Mahé : fiom near Morne Blane, about $800 \mathrm{ft}$, X.-XI. 1908 ; high forest of Morne Blauc and Pilot, X.-XI. 1908 ; Morne Seychellois, over $1500 \mathrm{ft}$. , 4. II. 1909 ; Mare aux Cochons district, 1500-2000 ft., I.—II. 1909 ; Cascade Estate, about $1000 \mathrm{ft}$. 1909. 
Oscrnis, Latreille.

Oscinis Latreille, Hist. Nat. Ins. et Crust., xiv. (1804), p. 385.

46. Oscinis dissimiticomis, n. sp.

This species has different coloured antennæ in the two sexes. This occurs also in O. dimorpha Osten-Sacken as described in "Diptera from the Philippine Islands," Berlin. Ent. Zeitschr., xxvi. (1882), p. 245. The present species differs in several respects; the head is pale, the wings non-infuscate, the hind femora and tibiæe are black instead of brown, the size is about $1 \frac{1}{2} \mathrm{~mm}$. instead of firm $2 \frac{1}{2}$ to 3 . 'They must be somewhat related forms.

6. Head. Frons yellow, dull; the frontal triangle is dull greyish-black with a broad base extending from eye to eye and a rounded fiont margin; it extends to about one-third of the distance from the vertex to the base of the antenne. Three pairs of fine upper fronto-orbital bristles, outer orbital bristles short but stout and slightly converging post-verticals, parallel upright ocellars one each side of the front ocellus. The rounded front margin of the frontal triangle has small bristles, and the frons is also provided with small bristles. Face whitish with small vibrisse; jowls pale yellow, a little less than one-third the vertical height of the eye; posterior eye-margins grey; back of head black.

Eyes oval, microscopically $(\times 16)$ pubescent.

Antennæe all yellow, arista black with slightly thickened basal joint, the rest being very finely pubescent.

Tongue black and chitinous.

Palpi yellow.

Thorax and scutellum dullish black with greyish yellow pollination and very short bristly hairs on the dorsum of both; the last dorso-central bristles present, two parallel terminal scutellar bristles and two shorter side ones. Plemra same colour as thorax; metanotum shining black.

Wings (Fig. 24) in no way infuscate, veins brown.

Halters with a rather elongate whitish head and pale yellow stalk.

Legs: front with yellow coxie, infuscate femora, the rest yellow; middle with infuscate coxæ and femora, the rest pale; hind also with infuscate coxæ and femora, the tibiæ generally infuscate basally.

Abdomen blackish, slightly shining and slightly paler at the base.

o differs in that the second and third antemal joints are black.

Size. $1 \frac{3}{4} \mathrm{~mm}$.

Localitics. Seychelles. Mahé: marsh just behind beach at Port Gland, 5. XI. 1908; marshes on coastal plain, Anse aux Pins and Anse Royale, 1. 1909. 
47. Oscinis acuticornis, n. sp.

This is the smallest species; it is entirely more or less shining black except for its paler legs and yellow halters, and can be at once recognised from its small size and the pointed tip to the large third antennal joint.

Head (Pl. 16, fig. 11). The frontal triangle is shiny black and practically covers the whole frons from the vertex to the rounded front margin just above the antenne, leaving only the eye-margins free. The face is deeply pitted between the eyes and below the lunula, and the antenne are partly sunk in this pit. Below the pit the face is seen to project when viewed in profile. Antennze black with a large hairy third joint ending in a small spike which is partly formed by a terminal thorn; arista blackish, stont and pubescent $(\times 45)$, second joint with a hair. Eyes microscopically pubescent.

The specinens are not in good condition but it is possible to see a fine fronto-orbital row of bristles, crossed post-rerticals and upright ocellars. Jowls about one-sixth of the height of the eye.

Thorax sparsely clothed with fine bristles, the last pair of dorso-centrals present. Scutellum slightly brassy with a rounded tip and two terminal bristles.

Wings (Fig. 25), veins dark brown.

Halters pale yellow.

Legs pale brown with darker femora.

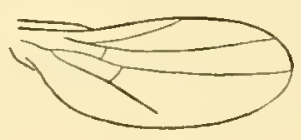

Fig. 25. Oscinis acuticomis, n. sp., wing.

Abdomen duller black than thorax.

Size about $\frac{3}{4} \mathrm{~mm}$.

Locality. Seychelles. Mahé : marshy ground near sea-level at Cascade, 20. II. 1909.

The following four species form a group of very similar species which are allied to O. atricomis Zett., and differ from the normal forms of the genus in their more slender shipe. They are shining black in colour and with wings whose length is in general unusually great relative to the body length. They are somewhat variable in colour of the legs and in the relative breadth and length of the wings. This is noticeably the case in the first species $(O$. oculuta) in which specimens occur which are exactly similar in all the important characters except that the wings (in the extreme cases) may vary between the forms given in Fig's. 26 and 27 . It is possible that further knowledge of the habits and food plants may enable the species to be more accurately subdivided.

48. Oscinis oculata, 12. sp.

f, ㅇ. Head (Pl. 16, figs. 12, 13). Frons black with a large shining frontal triangle (fig. 20), the base occupies very nearly the full space from eye to eye at the vertex, the 
sides are slightly convex, and the rounded apex extends nearly to the base of the antenna: two side triangles are thus formed between the eye-margins and the triangle which are duller than the central triangle and slightly purplish in colour. Five frontoorbital bristles, one vertical, crossed post-verticals, parallel ocellars. The face below the antenne and right up to the mouth margin is deeply recessed, the bottom of this pit or recess is paler than the rest and is sometimes quite yellowish. The mouth margin and hind head are shining black. 'The large sparsely pubescent eyes occupy nearly the whole of the head in side view (Pl. 16, fig. 12). The mouth margin is finely bristled, the bristles being of nearly equal size. Tongue, black, horny with a backwardly bent yellowish tip. Palpi black or blackish.

The antenne are black, the third joint large, orbicular and pubescent; arista black and strongly pubescent.

Thorax. Very shining black with fairly long bristly hairs on the dorsum, bent backwards, the last dorso-centrals present. Scutellum also shiny black with two end bristles situated a little dorsally of the rounded margin. Metanotum black and very shining.

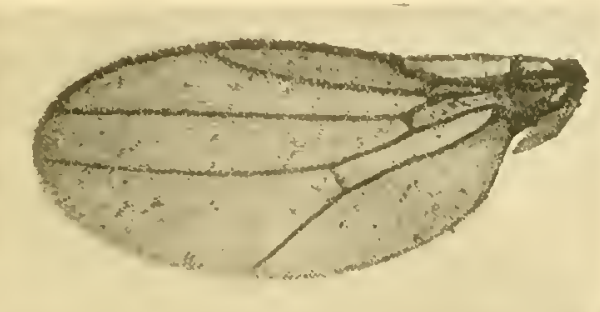

Fig. 26. Oscinis oculata, n. sp., wing.

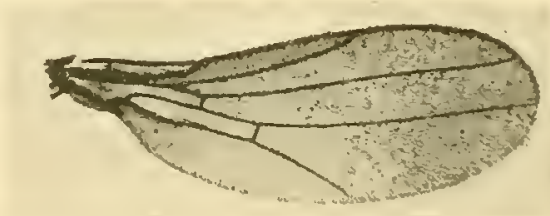

Fig. 27. Oscinis oculate, n. sp., var., wing.

Wings: the normal form is as shown in Fig. 26, the axillary lobe being well developed and the wing of normal outline. The second vein is always gently bent up to the costa, the third and fourth veins are quite parallel in their distal portions. In other specimens (which are in other respects indistinguishable) the wings are different in form. In some the wings are of the shape given in Fig. 26, but are proportionately shorter; while the normal wing has its length about 2.4 times the maximum breadth, in the present case the ratio falls below $2 \cdot 3$ : this form has usually slightly darker legs than the typical form. A more extreme form occurs in which the shape of the wing is altered, as shown in Fig. 27: the axillary lobe is smaller, and the wing is more "bat" shaped; the above ratio has here a value of 3 to 1 . All the forms occur together; and are more or less connected by intermediates. It is possible that the form figured in Fig. 27 is a distinct species, although in other respects it is practically identical with the normal type. The veins are brownish.

\section{Halters pale.}

The legs are also slightly variable in colour; in most cases they are yellow with various degrees of infuscation. The commonest form is as follows: front legs (including coxi) yellow; middle legrs, coxie black, femora very slightly infuscate on the distal half 
or two-thirds, tibixe and tarsi yellow; hind legs, coxa black, femora slightly infuscate, tibix with an infuscate ring, tarsi yellow. In some specimens the infuscation is confined to the ring on the hind tibix, and more rarely the legs are entirely yellow.

Abdomen. Shining black, sometimes paler at the base; venter pale.

Size. $1 \frac{3}{4}$ to $2 \mathrm{~mm}$.

Localities. Seychelles. Silhouette: high forest, $2000 \mathrm{ft}$; near Mont Pot-ì-eau, about 1500 ft., VIII. 1908; Mare aux Cochons platean and forest above, VIII._IX. 1908; low coconut-planted country near coast, Pointe Étienne, 17. IX. 1908. Mahé: near Morne Blanc, about $800 \mathrm{ft} .$, X.-XI. 1908; high forest of Morne Blanc and Pilot, X.-XI. 1908; Cascade Estate, abont $1000 \mathrm{ft}$, and forest above up to $2000 \mathrm{ft}$., 1.908-9; Mare aux Cochons district, 1500 -2000 ft., I.-II. 1909; Morne Seychellois, over $1500 \mathrm{ft.}$, 4. II. 1909. Praslin: Côtes d'Or Estate, X. 1908.

49. Oscinis longipennis, 11. sp.

This species is like the European O. atricomis Zett.

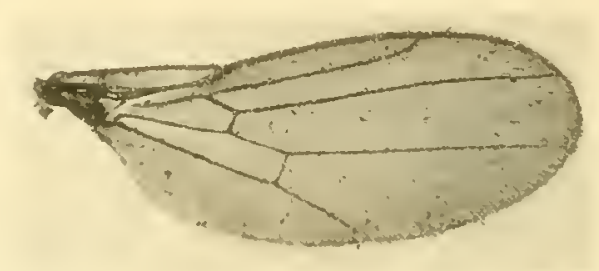

Fig. 2.8. Oscinis longipennis, n. sp., wing.

f, f. Head (PI. 16, figs. 14, 15). Frons dull rufous black with a very shining frontal triangle which is less broad at the base than in the last species (Pl. 16, fig. 13) and has a somewhat pointed apex which does not quite reach the antennæ. Five fiontoorbital bristles, two verticals each side, crossed post-verticals, convergent ocellars; the frontal triangle with well narked bordering bristles. Face in profile more retreating than in last species (fig. 23), with a long pit-like furrow in the centre which is yellowish at the bottom. Mouth margin shining black with bordering bristles, the upper pair of which are longer and form vibrisse. Hind head shining black, lower eye-margins dull. Tongue and palpi blackish.

Eyes microscopically pubescent.

Antennæ black, third joint orbicular, arista black and pubescent, second joint slightly paler.

Thorax and scutellum as the last species.

Wings as Fig. 28: the second vein is straight almost to the end where it suddenly turns up to the costa; the third and fourth veins slightly and continuously divergent. The wings are exceptionally long and ample and extend far beyond the tip of the body: they are slightly suffused with brown and have brown veins.

Halters yellow.

Legs entirely yellow except the middle and hind coxie and occasionally a slight infuscation on the hind tibice. 
Abdomen. Black, sometimes a little paler at the base. of with a short fine oripositor.

Size about 2 min.

Localities. Seychelles. Silhonette: liighest forest, $2000 \mathrm{ft}$; near Mont Pot-à-eau, about $1500 \mathrm{ft.}$., VIII. 1908; Mare anx Cochons and forest above, IX. 1908. Mahé: ligh forest of Morne Blanc and Pilot, X.-XI. 1908: Mare aux Cochons district, 1500-2000 ft. I.-II. 1909; Cascade Estate, about 1000 ft., 1908-9.

50. Oscinis halterata, n. sp.

This species is similar in form of venation to O. longipemis: it is also entirely shining black.

Head (Pl. 16, figs. 16, 17). Somewhat as $O$. oculata but the jowls are just visible in profile; they are grey in colour. The antennæ are not deep black, but very dark brownish or reddish black, and reddish on the inner faces.

Thorax. Scutellum and wings as in O. longipennis, but the cross veins are nearer together and the wings are slightly shorter.

Halters black.

Legs yellow with all the femora and the middle and hind tibie slightly darkened.

Abdomen. Shorter and dark haired. of with a long ovipositor.

Size about $1 \frac{1}{2} \mathrm{~mm}$.

Locculities. Seychelles. Mahé: marshes on coastal plain, Anse aux Pins and Anse Royale, I. 1909; Anonyme Island, I. 1909.

51. Oscinis variconnis, n. sp.

Two specimens can be referred to another species. In the characters of thorax, wings, legs and abdomen it is like $O$. longipennis except that the wings are slightly shorter in proportion and the halters are infuscate and not clear yellow. The chief differences are in the head.

Head (Pl. 16, fig. 18). Side view as figured, well marked jowls being present and the mouth margin slightly projecting. The frontal triangle is much as in O. longipennis. the eye-margins black and shiny; the facial pit is less deep and slightly wider.

The third joint of the antennæ is red on the lower half and black on the upper, the arista is perceptibly pale at the extreme base.

In other respects the insect is very like O. longipennis, but the legs are clear orange yellow.

Size. $2 \frac{1}{4} \mathrm{~mm}$.

Localities. Seychelles. Mahé: country above Port Glaud, 500-800 ft., 5. XI. 1908; marshes on coastal plain, Anse aux Pins and Anse Royale, I. 1909. 


\section{Agromyzidae.}

Agromyza, Fallén.

Agromyza Fallén, Dipt. Suec., Agromyz., iii. (1823), p. .

5:. Agromyza pubicomis, n. sp.

This species is one of the relatively longer and more parallel forms; in shape it resembles a small $A$. capitata.

Head (Pl. 16, fig. 19). Frons dull yellow with a black somewhat shining ocellar spot; the lunula is sunk into the frons leaving somewhat projecting yellow eye-margins, it extends from the base of the antemne nearly half way back to the ocellar spot and is grey in colour, the upper rounded edge being somewhat silvery. Face, tongue, palpi, jowls and margins behind eyes yellow; back of head black; the jowls project somewhat and there are well marked vibrissæe.

Antennre; first two joints yellow, the third greyish but yellow inside near the base, second joint with a fine bristle; arista somewhat thickened especially at the base which is rellow the rest being darkened, the pubescence is well marked, stout and close set.

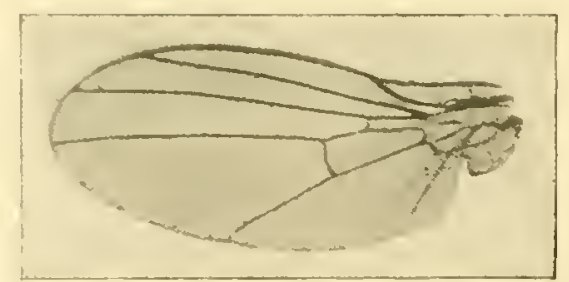

Fig. 29. Agromyza pubicomis, u. sp., wing.

Four fronto-orbital bristles, lower two fine and pointing inwards, upper two stouter and pointing outwards; stout inner verticals nearly parallel, finer outer verticals; ocellars parallel and forwardly directed; post-verticals divergent.

Thorax. Dorsum and pleure slightly shining black $(1+3)$, rather unequal dorsocentral bristles; achrostical bristles in four well marked rows. Scutellum black and somewhat pointed with four long and nearly equal bristles, the terminal pair fairly close together, the other pair near the base and somewhat remote from the margin.

Tings as Fig. 29, glassy with brown veins.

Halters bright yellow.

Legs yellow with slightly infuscate tibie and tarsi.

Abdomen somewhat shining black with approximately equal segments, covered dorsally with short bristles.

Size. $1 \frac{4}{5} \mathrm{~mm}$.

Locutities. Sejchelles. Mahé: marshy ground near sea-level at Cascade, 20. II. 1909; marshes on coastal plain, Anse aux Pins and Anse Royale, I. 1909. 
The following species are more rounded in form, resembling $A$. aneiventris, Fallén.

53. Agromyza funclieis, n. sp.

Two specimens were collected of this species which is entirely somewhat dull black in colour'.

Head (Pl. 16, fig. 20). Frons dull brown black; a well marked frontal triangle, and broad eye-margins separated from the rest of the frons by a browner space. The frontoorbital bristles stand on small shining spots. Face with the base of the antennie rather. sunk in, so that the first joint of the latter is hidden. Autenna black with a very small thick third joint and pubescent arista. Jowls very narrow, nouth margin slight] prominent; vibrissie small.

Four fronto-orbital bristles which do not converge, inner and outer verticals of about the same length; parallel ocellars, divergent post-verticals.

Thorax. Subquadrate, apparently with only two dorso-central bristles and many irregular achrostical bristles. Scutellum rounded in outline with four bristles.

Wings glassy with brown veins; the veins as in Fig. 30, where the basal part is left out as it could not be properly seen.

Halters black.

Legs all black.

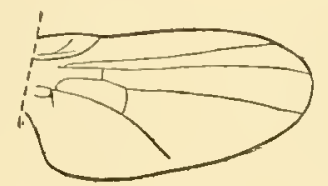

Fig. 30. Agromyza funebris, n. sp., wing.

Abdomen all black clothed with short bristles.

Size. $1 \frac{1}{3} \mathrm{~mm}$.

Localities. Seychelles. Silhonette: near Mont Pot-ì-eau, about $1500 \mathrm{ft.}$, VIII. 1908. Mahé: Cascade Estate, about $1000 \mathrm{ft}$.

54. Agromyza candidipennis, n. sp.

'This is an entirely shining black insect with markedly milky wings.

Head (Pl. 16, fig. 21). Vertex and frons entirely black, rather shining; the frontal triangle more shining with its base about one-half the distance between the eyes, with a pointed end, the sides slightly concave, it extends about two-thirds of the way from the vertex to the boundary of the lunula. The lunula is ronglily semicircular in outline. Eye-margins shining like the frontal triangle. Face black, sunk in from the lunula to the mouth-margin so that in profile the base of the antenne is hidden. Palpi short and stont, somewhat swollen; tongue brownish.

Eyes large, bare.

Antennæ black, second joint with a bristle; third joint rounded and rather small, arista black and bare $(\times 45)$. Fronto-orbital bristles four, equally spaced and somerhat convergent; long inner and shorter outer verticals, ocellars, and divergent post-verticals. 
Thorax. Dorsum shining metallic greenish black; almost metallic green in a bright light; entirely covered with fine bristles; the last dorso-centrals present. Scutellum with four bristles, the terminal pair small and crossed. Pleura shining black but reddish just below the wing insertion.

Wings as Fig. 31; milky white with white veins; the costa finely bordered with a brown line.

Halters black.

Legs all black, femora with a well marked shallow groove below into which the tibire can fit.

Abdomen. Dark greenish black; the last segment very long, about equal in length to the previous three segments. The male has a globular hypopygium, the female a stout blunt cylindrical ovipositor; the last segment of the female has a fringe of extra long black hairs.

Size about $1 \frac{3}{4} \mathrm{~mm}$.

Localities. Seychelles. Silhouette: Mare aux Cochons, IX. 1908; low coconut-planted country near coast, Pointe Étienne, 17. IX. 1908. Nahé : Port Victoria, XII. 1908.

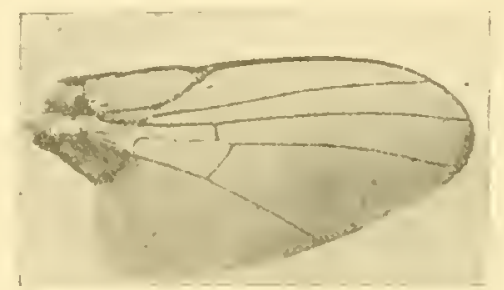

Figs. 31. Agromyza candidipennis, n. sp., wing.

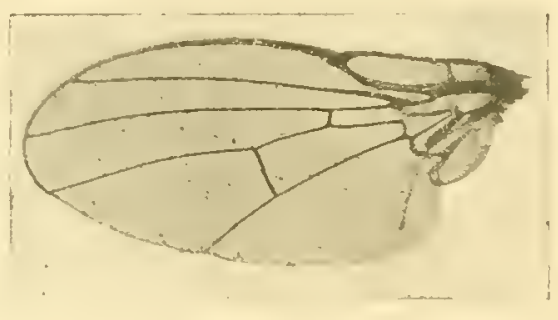

Fig. 32. Agromyza similis, n. sp, wing.

55. Agromyza similis, n. sp.

This species is very closely allied to the Palæarctic $A$. ceneiventris Fallén.

Head. In general outline and chætotaxy much as the last species except that the eyes are slightly less high in proportion to their breadth; the facial pit is also flatter at the bottom. The arista is distinctly pubescent $(\times 45)$. The lunula is not evident, being sunk in with the rest of the face just above the antennæ.

Thorax as last species.

Wings as Fig. 32: glassy with brown reins.

Halters and legs all black.

Abdomen. Greenish black with practically equal sized segments, के hypopygium and of ovipositor fir less conspicuous.

Size about $2 \mathrm{~mm}$.

Loculities. Śychelles. Silhonette: cultivated country; low coconut-planted country near coast, Pointe Étienne, 17. IX. 1908; Mare aux Cochons and forest above, IX. 1908. Mahé: from near Norne Blane, about $800 \mathrm{ft.}$ X.-XI. 1908; Cascade Estate, about $1000 \mathrm{ft}$; marshy ground near sea-level at Cascade, 20. II. 1909. 


\section{Agromyza sp.?}

A single specimen of another species is in the collection, but it is not in sufficiently good condition to warrant a full description.

The insect is in form, size, etc. very close to the last species; but it is of a moderately shining and of a true black colour, including halters and legs. The head is black and very similar to the last species, but the third antenne joint is small and slightly pointed, and the arista is bare and shorter than usual. 'The chatotaxy camnot be given owing to the damaged condition. The wing venation is shown in Fig. 33 ; the wings are slightly milky with yellow veins and a fine dark costal line.

Locclity. Seychelles. Mahé: Mare aux Cochons district, 1500-2000 ft., I.-II. 1909.

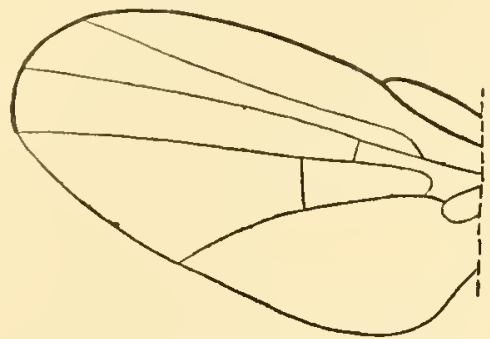

Fig. 33. Ayromyzd, sp.?, wing.

\section{Agromyzce sp.?}

A second single imperfect specimen. No description can be given in any detail, but the insect has a remarkable month-margin, produced each side into a pointed lobe, which terminates in a long slightly curved white spine. The insect is quite black; wings pale with brown veins; discal cross-rein just about opposite the junction of the first vein with the costa, and the relative position of the two cross-veins just about as shown in Fig. 33 ; though the terminal section of the fifth vein is shorter than the part bordering the discal cell, instead of being of about the same length.

Locality. Chagos Islands: Salomon Atoll, Île de Passe; bred from mines in Sccerola Íxnigii (1905).

\section{Leucopis, Neigen.}

Leucopis Meigen, Syst. Beschr., xi. (1830), p. 133.

58. Lencopis griscola (Fallén), Dipt. Suec., Agromyz., (1823), p. 8 [Anthomyza].

There is a fairly long series of a species of this genus; they exhibit no structural differences from the above species, but are on the average somewhat smaller in size, being from $1 \frac{1}{2}$ to $1 \frac{3}{4} \mathrm{~mm}$. long. The legs are not quite so definitely coloured and the third antennal joint is in most cases slightly larger. It is impossible to separate the specimens satisfactorily from the members of the series of $L$. griseola in the Cambridge Museum.

Localities. Seychelles. Silhouette: Mare aux Cochons platean and forest above, IX. 1908; Mahé: country above Port Glaud, 500-800 ft., 5. X. . 1908; Port Victoria, XII. 1908; Cascade Estate, about 1000 ft.; Anonyme Island, I. 1909; marshes on coastal plain, Anse aux Pins and Anse Royale, I. 1909. Also known from the Canary Islands. 


\section{EXPLANATION OF PLATES 15 AND 16.}

\section{Plate 15.}

Fig. 1. Lonchcea plumata, n. sp., liead $\times$ 3.j.

Fig. 2.

Fig. 3. " longicornis, n. sp., head $\times 20$.

Fig. 4. "vibrissifer, 1. sp., head $\times 20$.

Fig. 5. Pachycerina seychellensis, n. sp., $\delta$, abdomen $\times 20$.

Fig. 6.

Fig. 7. Sapromyza striata, n. sp., head $\times 20$.

Fig. S. " funebricurnis, n. sp., head $\times 20$.

Fig. 9. " mahensis, 11. sp., tip of abdomen $\times 20$.

Fig. 10. " " $\quad$ u. sp., tip of abdomen $\times 20$.

Fig. 11. " mudiuscula, n. sp., head $\times 20$.

Fig. 12. " crassicaput, n. sp., head $\times 20$.

Fig. 13. " perpunctate, n. s]., head $\times 20$.

Fig. 14. Homoneura varifrons, n. sp., head $\times 20$.

Fig. 15. Hecamede lacteipennis, n. sp., head $\times 15$.

Fig. 16. Psilopa longicornis, n. sp., head $\times 25$.

Fig. 17. I'urydra tuberculifera, n. sp., front femur $\times 25$.

Fig. 18. " " n. sp., head $\times 25$.

Fig. 19. Canace makensis, 11. sp., $\times 22$.

Fig. 20. Allotrichoma argentiprcetexta, n. sp., head $\times 20$.

Fig. 21. Enchastes scotti, n. g. et n. sp., $\times 15$.

Fig. 22. " " n. g. et n. sp., head $\times 2.5$.

Fig. 23. Acanthonotiphila curiacea, n. g. et n. sp., $\times 22$.

\section{Plate 16.}

Fig. 1. Ops glaberrima, n. sp., head, side view $\times 20$.

Fig. 2. " " n. sp., head, top view $\times 20$.

Fig. 3. " " n. sp., thorneic dorsum.

Fig. 4. " " $\quad$ แ. sp., var. dentata, 11. var., thoracic dorsum $\times 20$.

Fig. 5. Gunpsocera scutellata, n. sp., thoracic dorsum $\times 20$.

Fig. 6. Meroscinis ceneifrons, 11. sp., head, side view $\times 25$.

Fig. 7. " " $\quad$ n. sp., head, top view $\times 25$.

Fig. S. " "rugosu, 11. sp., head, top riew $\times 25$.

Fig. 9. Hippelates longisetu, n. sp., head $\times 30$.

Fig. 10. Guurax seychellensis, n. sp., head $\times 25$.

Fig. 11. Oscinis acuticomis, 上. sp., head $\times 4$.

Fig. 12. " oculata, n. sp., head, side view $\times 25$.

Fig. 13. " " 13. sp., head, top view $\times$ 2.5.

Fig. 14. " longipennis, n. sp., head, side view $\times \mathbf{2 5}$.

Fig. 15. " $"$ n. sp., head, top riew $\times 25$.

Fig. 16. " halterata, n. sp., head, side view $\times 25$.

Fig. 17. " " $"$ n. sp, head, top view $\times 25$.

Fig. 18. " varicurnis, 11 sp., head $\times 25$.

Fig. 19. Agromyzu pubicurnis, n. s]., head $\times 2.5$.

Fig. 20. " funebris, n. sp., head $\times 20$.

Fig. 21. " $\quad$ condidipennis, n. sp., head $\times$ 2.5. 

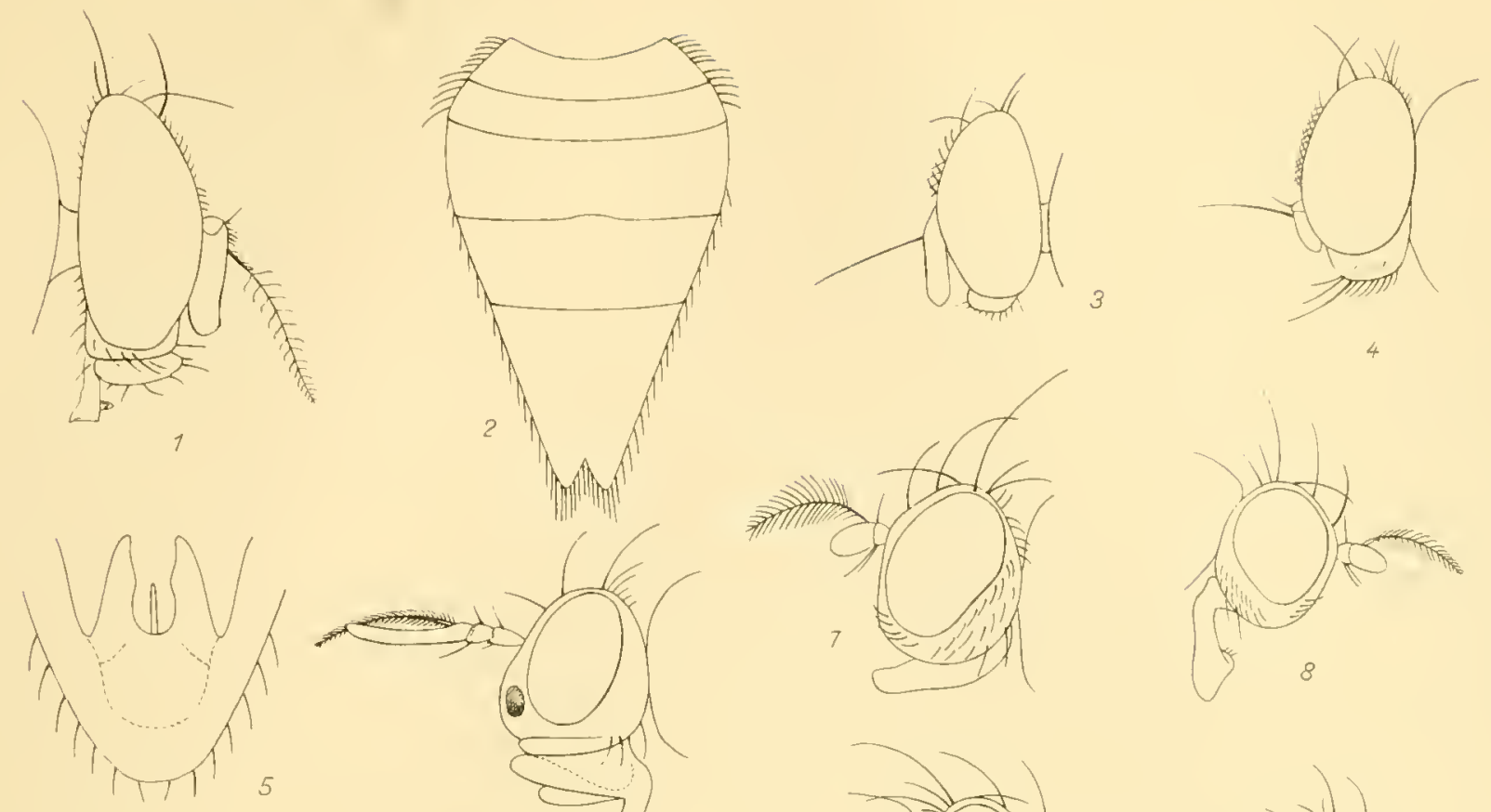

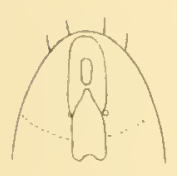

9

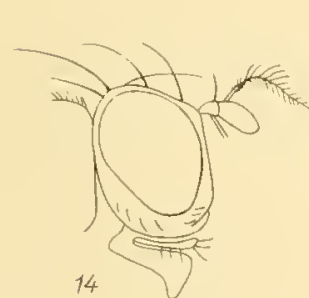

14

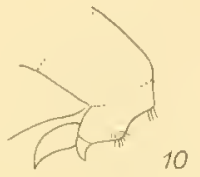

10

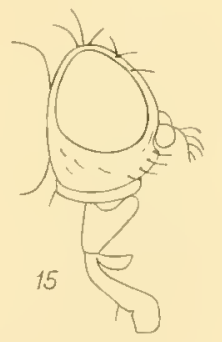

$20 \int_{-3}^{1}$
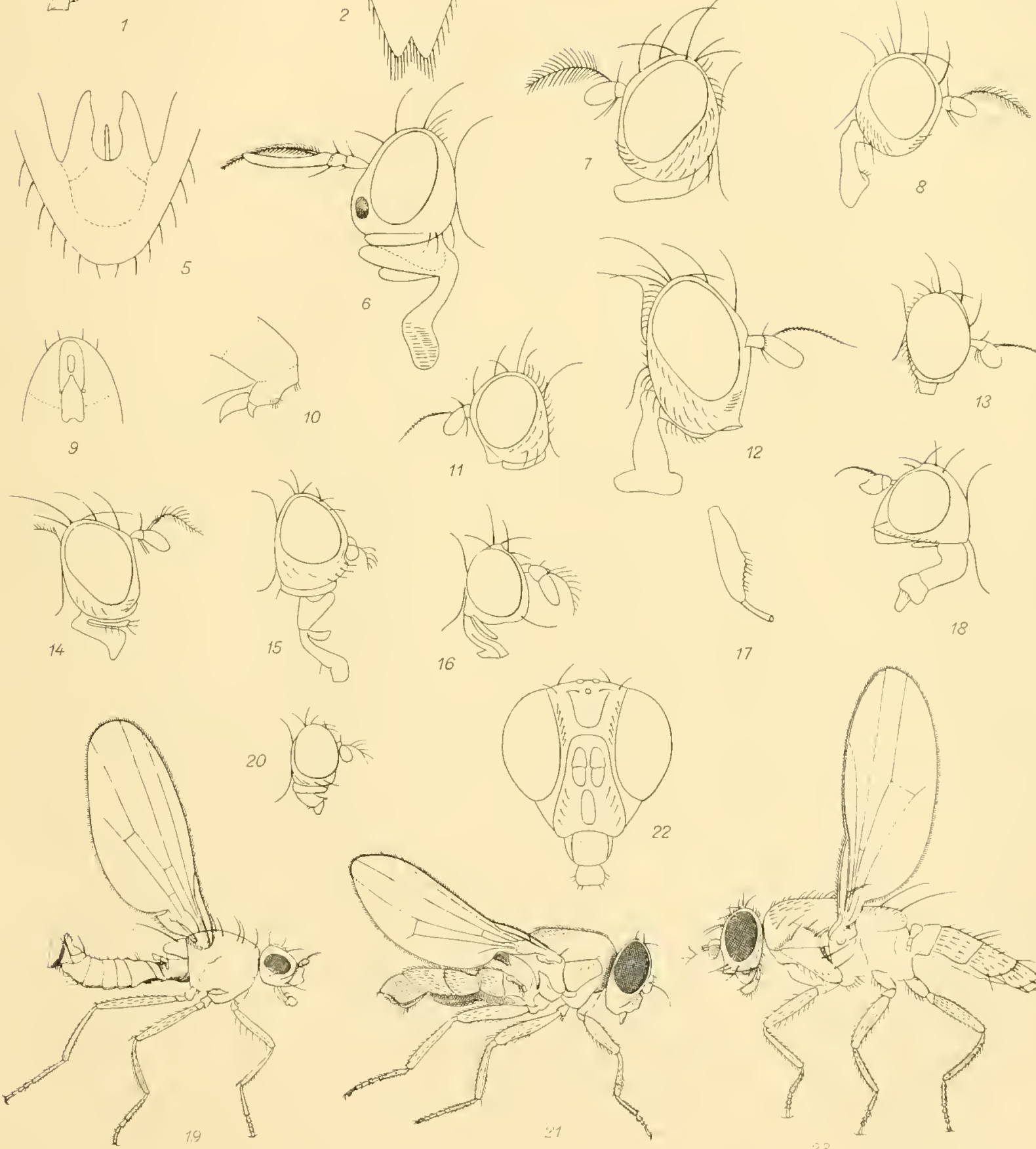

SLet, EWits]
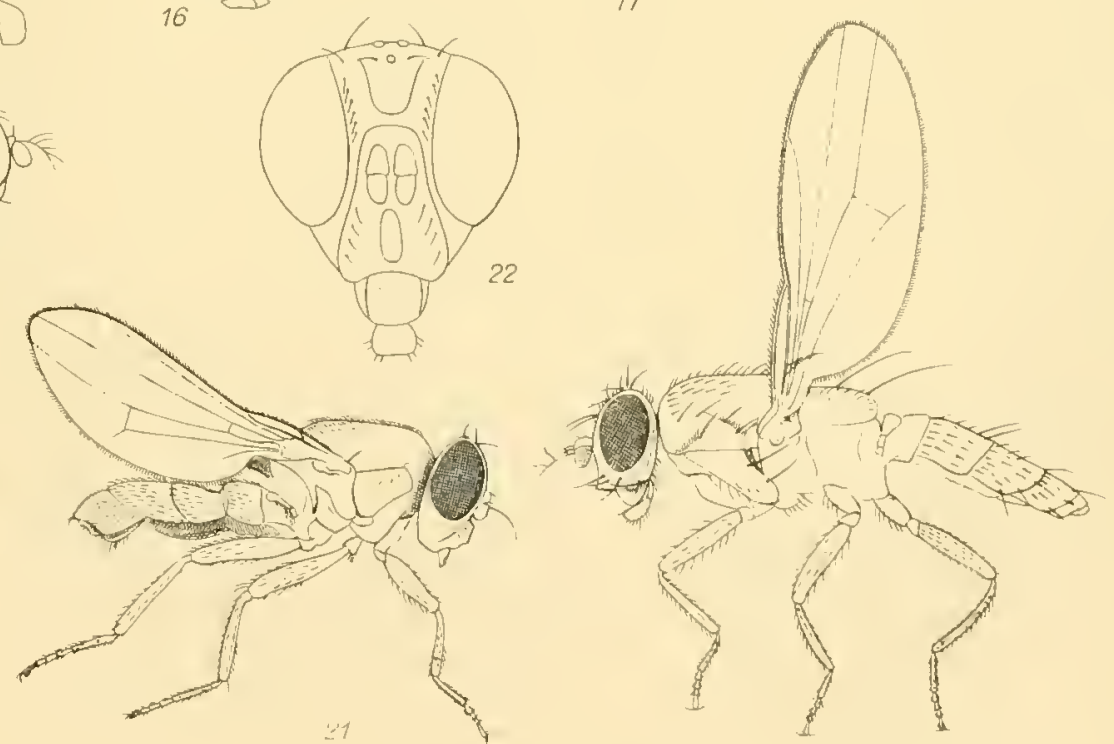

E Wilson, Cambridot 

PERCY SLADEN TRUST EXPEDITIUN. ( $L A M B$ )

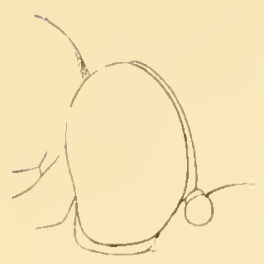

7

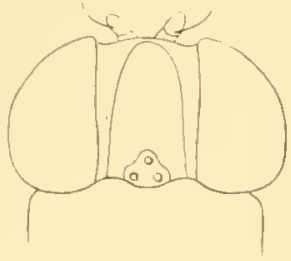

2

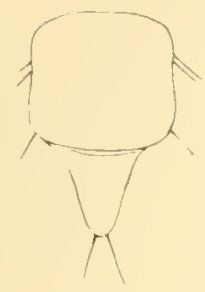

5

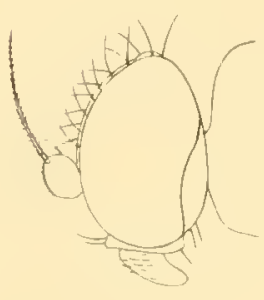

6

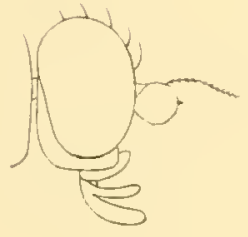

17<smiles>CCCC1CCCCC1C</smiles>

10

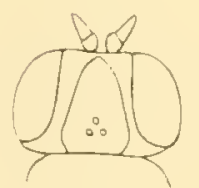

15

14

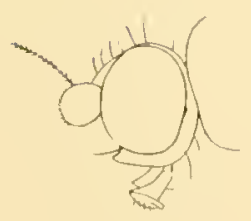

12

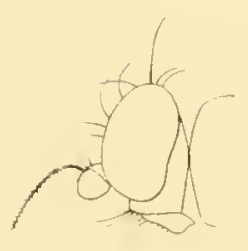

19

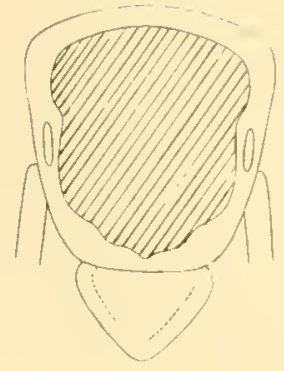

3
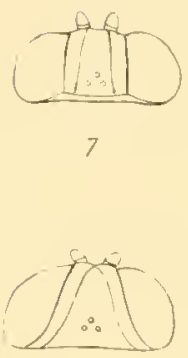

8

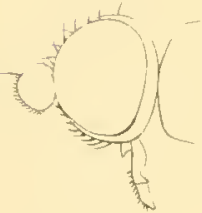

12

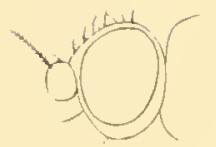

16<smiles>CC1CC=CC(C)C(C)CC1</smiles>

20

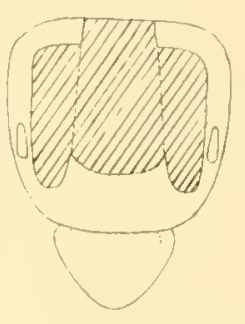

4

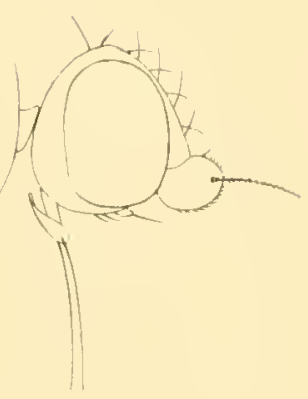

9

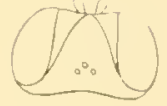

13

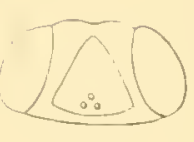

17

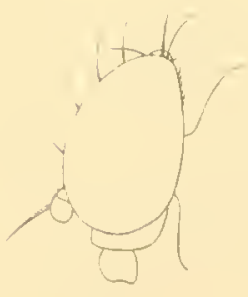

27

- 




\section{LINNEAN SOCIETY OF LONDON.}

\section{MEMORANDA CONCERNING 'TRANSAC'TIONS.}

The First Series of the Transactions, containing both Botanical and Zoological contributions, has been completed in 30 Vols., and a few entire sets are still for sale. Only certain single volumes, or parts to complete sets, may be obtained at the original prices. The price of the Index to Vols. 1-25 is $8 s$. to the public, and 6s. to Fellows; to Vols. 26-30, 4s. to the public, and 3s. to Fellows.

The Second Series of the 'Transactions is livided into Zoological and Botanical sections. The prices of the Zoological parts of those which have been published are as uudermentioned:-

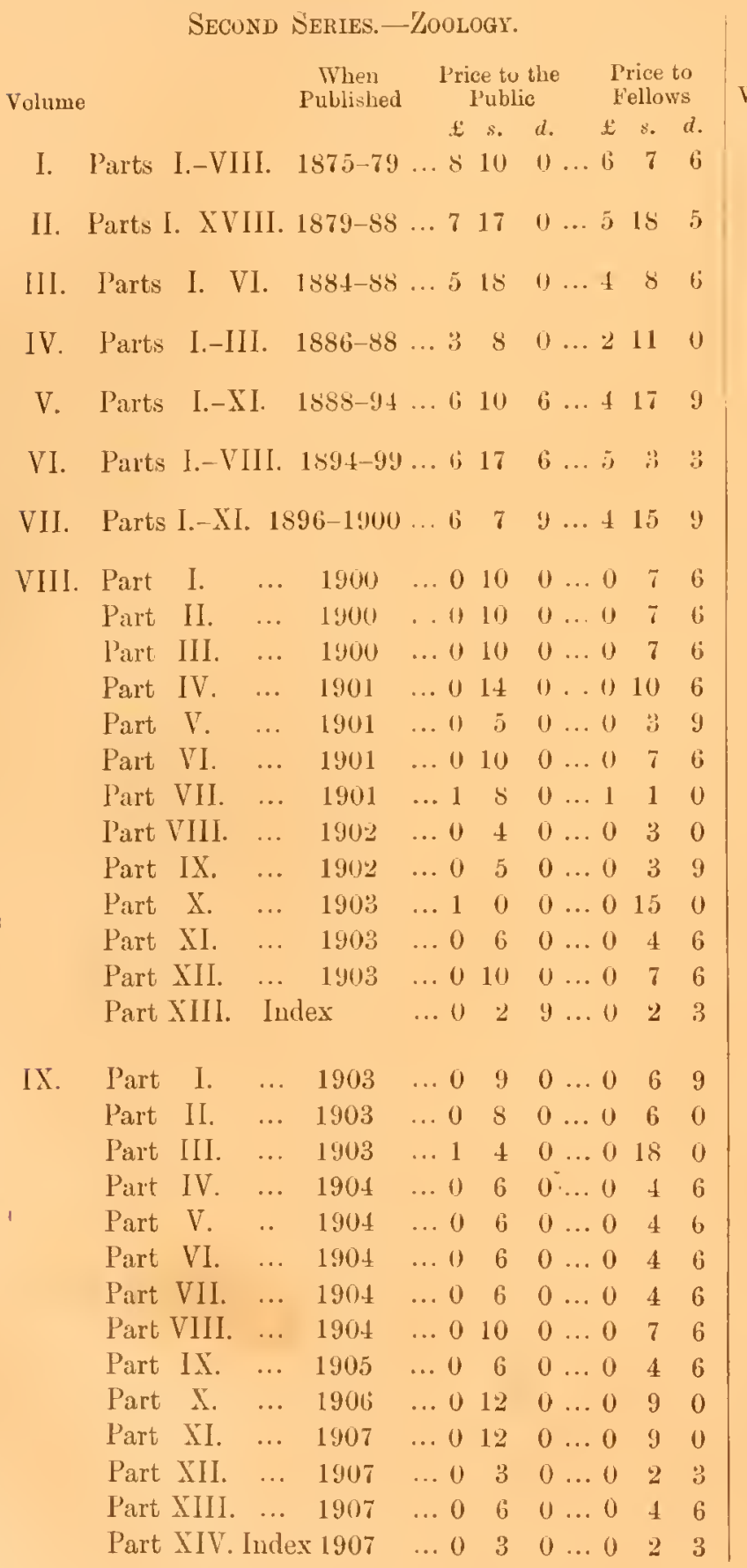

Second Series. - Zoology (continued).

Volume

$\mathrm{X}$.

.

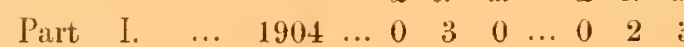

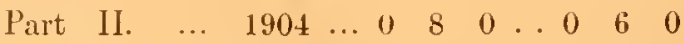

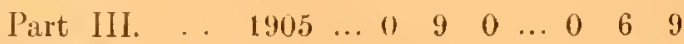

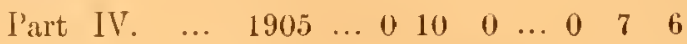

$\begin{array}{lllllllllll}\text { Part V. } & . . & 1906 & \ldots & 0 & 7 & 6 & \ldots & 0 & 5 & 3\end{array}$

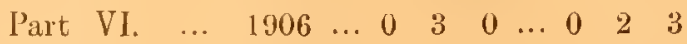

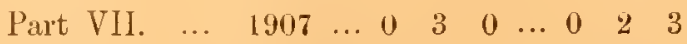

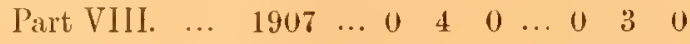

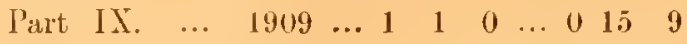

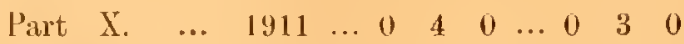
(In progress.)

XI. Part I. $\quad \begin{array}{lllllllllll} & 1908 & \ldots & 0 & 4 & 0 & \ldots & 0 & 3 & 0\end{array}$

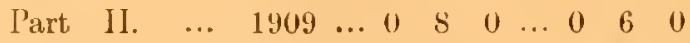

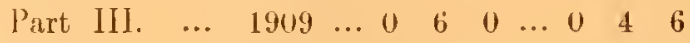

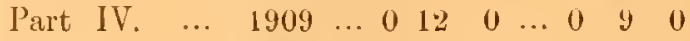

$\begin{array}{lllllllllll}\text { Part V. } & \ldots & 1909 & \ldots & 0 & 2 & 0 & \ldots & 0 & 1 & 6\end{array}$

l'art VI. $\quad \ldots \quad 1910$... 01011

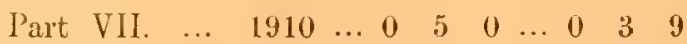

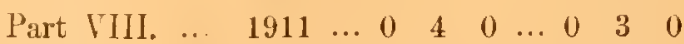

$\begin{array}{llllllllllll}\text { Part IX. } & \ldots & 1911 & \ldots & 0 & 2 & 6 & \ldots & 0 & 2 & 0\end{array}$

$\begin{array}{llllllllllll}\text { Part X. } & \ldots & 1911 & \ldots & 0 & 2 & 6 & \ldots & 0 & 2 & 0\end{array}$ (In progress.)

XII. Part I. $\quad \ldots \ldots \begin{array}{llllllllll} & 1907 & \ldots & 1 & 8 & 0 & \ldots & 1 & 1 & 0\end{array}$

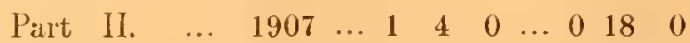

Part 1II. $\ldots .1908 \ldots \begin{array}{llllllll}0 & 16 & 0 & \ldots & 0 & 12 & 0\end{array}$

$\begin{array}{lllllllllll}\text { Part IV. } & \ldots & 1909 & \ldots & 1 & 10 & 0 & \ldots & 1 & 2 & 6\end{array}$

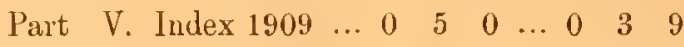

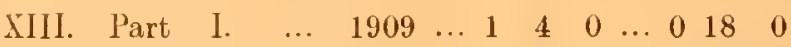

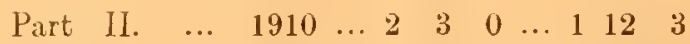

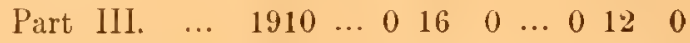

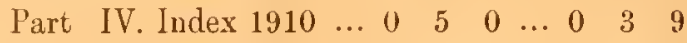

XIV. Part I. $\quad \ldots \begin{array}{llllllllll}1910 & \ldots & 1 & 18 & 0 & \ldots & 1 & 8 & 6\end{array}$

$\begin{array}{llllllllllll}\text { Part II. } & \ldots & 1911 & \ldots & 1 & 0 & 0 & \ldots & 0 & 15 & 0\end{array}$

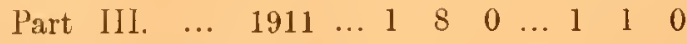

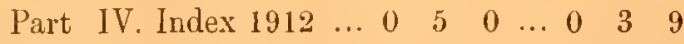

XV. Part I. $\quad \ldots \begin{array}{llllllllll}1912 & \ldots & 1 & 9 & 0 & \ldots & 1 & 1 & 9\end{array}$

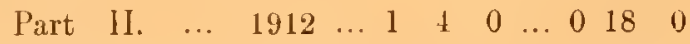

$\begin{array}{llllllllllll}\text { Part III. } & \ldots & 1912 & \ldots & 1 & 6 & 0 & \ldots & 0 & 19 & 6\end{array}$

Part IV. ... (In preparation.) 






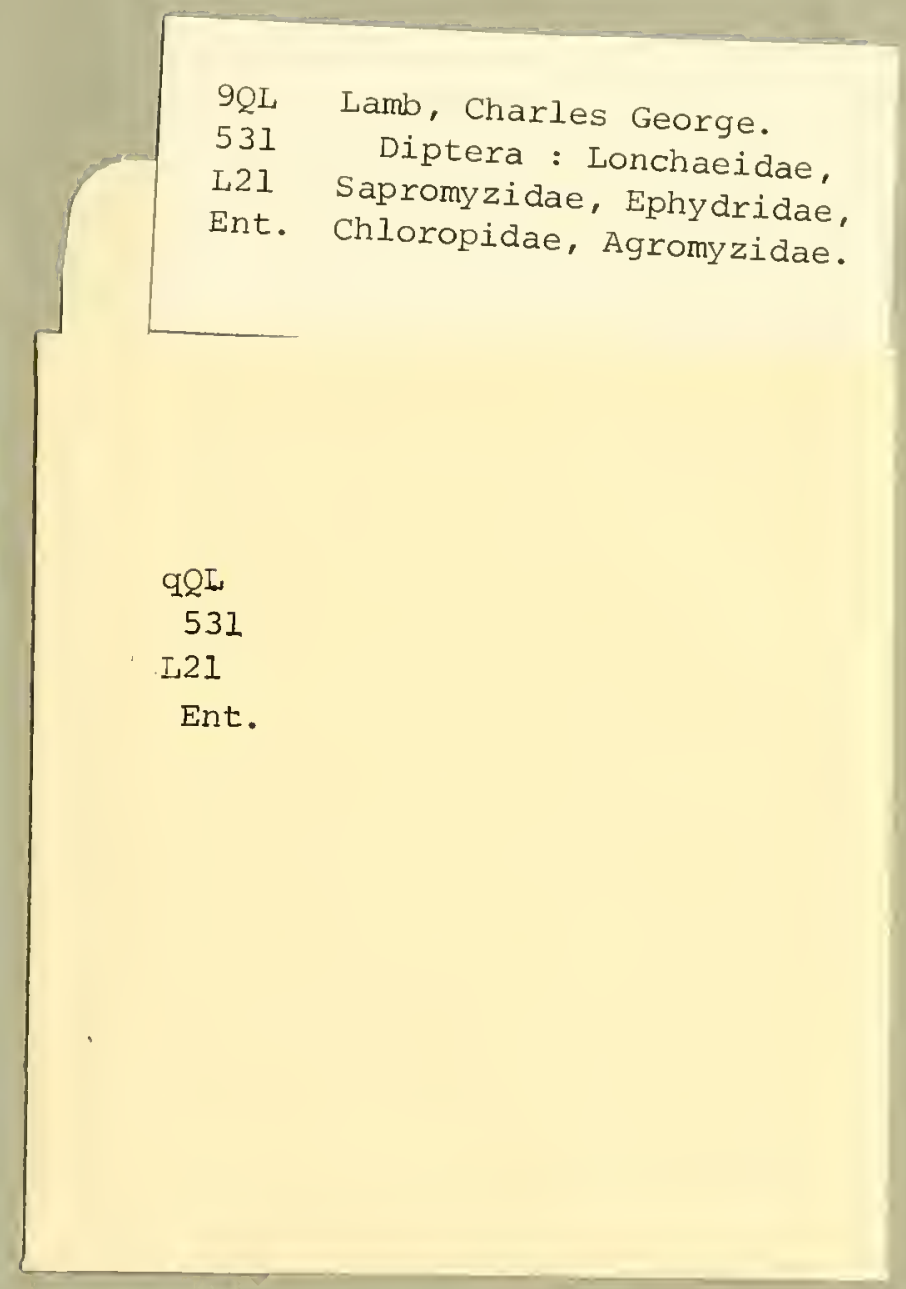


